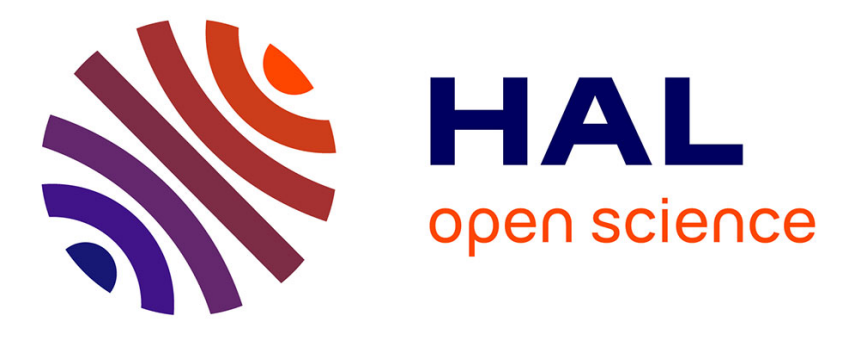

\title{
Maleimide-based metal-free ligation with dienes: a comparative study
}

Alexis Lossouarn, Kévin Renault, Laëtitia Bailly, Axel Frisby, Patricia Le Nahenec-Martel, Pierre-Yves Renard, Cyrille Sabot

\section{- To cite this version:}

Alexis Lossouarn, Kévin Renault, Laëtitia Bailly, Axel Frisby, Patricia Le Nahenec-Martel, et al.. Maleimide-based metal-free ligation with dienes: a comparative study. Organic \& Biomolecular Chemistry, 2020, 18 (20), pp.3874-3887. 10.1039/D0OB00403K . hal-03010566

\section{HAL Id: hal-03010566 \\ https://hal-normandie-univ.archives-ouvertes.fr/hal-03010566}

Submitted on 17 Nov 2020

HAL is a multi-disciplinary open access archive for the deposit and dissemination of scientific research documents, whether they are published or not. The documents may come from teaching and research institutions in France or abroad, or from public or private research centers.
L'archive ouverte pluridisciplinaire HAL, est destinée au dépôt et à la diffusion de documents scientifiques de niveau recherche, publiés ou non, émanant des établissements d'enseignement et de recherche français ou étrangers, des laboratoires publics ou privés. 


\section{ARTICLE}

\section{Maleimide-based metal-free ligation with dienes: a comparative study}

Received 00th January 20xx, DOI: $10.1039 / \times 0 \times x 00000 x$ Accepted 00th January 20xx

\author{
Alexis Lossouarn, ${ }^{a}$ Kévin Renault, ${ }^{a}$ Laetitia Bailly, ${ }^{a}$ Axel Frisby, ${ }^{a}$ Patricia Le Nahenec-Martel, \\ Pierre-Yves Renard, ${ }^{a}$ and Cyrille Sabot*a
}

\begin{abstract}
A brief literature survey reveals that metal-free ligation such as the maleimide-based cycloaddition with electron-rich (hetero)dienes is a widespread tool for the assembly of (bio)molecular systems with applications in biotechnology, materials science, polymers and bio-organic chemistry. Despite their everyday use, only scattered data about their kinetics as well as the stabilities of corresponding products under physiological conditions, are accessible. These key parameters are yet, of paramount importance to ensure the rapid and effective preparation of stable compounds. Herein is reported a systematic study regarding the different classes of dienes used in chemoselective ligation, including their accessibility and stability, as well as comparative kinetic experiments and products stability assays. We took advantage of these data to develop a double labeling strategy from the combined use of cyclopentadiene and oxazole dienes.
\end{abstract}

\section{Introduction}

Maleimide is indisputably a privileged scaffold for the design of biomolecular systems and tailor-made materials that are finding widespread utility in biotechnology, polymer and materials science. ${ }^{1-4}$ The constant interest in maleimide derivatives is partly due to their remarkable reactivity, chemoselectivity, stability, and to the fact that a wide range of maleimide-activated labels are now commercially available (Figure 1). Moreover, maleimide-based chemical reactions proceed under metal-free and physiological conditions suitable for biomolecules modification.

On the one hand, maleimide readily undergoes Michael addition with thiols or biothiols and prominent examples in this context include the design of marketed antibody-drug conjugate (ADCs), like Kadcyla and Adcetris used for cancer treatment. $^{5}$ On the other hand, this cyclic electron-poor system is a particularly convenient dienophile partner for Diels-Alder (D-A) cycloaddition reactions with diene-modified (bio)molecules, which have been exploited for the site-specific derivatization of peptides and proteins, ${ }^{6-8}$ monoclonal antibodies, ${ }^{9,10}$ oligonucleotides, ${ }^{11-14}$ polysaccharides, as well as for their immobilization on surface. ${ }^{15,16}$ In this context, recent examples include the preparation of carbohydrate-based affinity adsorbents by Fort and coworkers through a furan/maleimide strategy for immobilizing oligosaccharides on solid matrices. ${ }^{16}$ The resulting glycoconjugates were used for the purification of lectins and the capture of anti-blood-group

\footnotetext{
a. Normandie Univ, CNRS, UNIROUEN, INSA Rouen, COBRA (UMR 6014), 76000 Rouen (France). E-mail: cyrille.sabot@univ-rouen.fr

Electronic Supplementary Information (ESI) available: [details of any supplementary information available should be included here]. See
}

A and -B antibodies. In addition, Read de Alaniz and Christie reported the production of an antibody-drug conjugate by reacting the maleimide-based drug-linker AZ1508 with a cyclopentadiene-based non canonical lysine residue genetically incorporated into the human $\operatorname{lgG} 1$ antibody. ${ }^{17}$ Finally, Overkleeft and coworkers demonstrated the applicability of the maleimide-based D-A strategy for monitoring the activity of endogenously expressed proteases in cellular extracts. ${ }^{18}$<smiles>O=C(O)CN1CCCN(CC(=O)O)CCN(CC(=O)NCCN2C(=O)C=CC2=O)CC1</smiles><smiles>CC1(C)CC(N2C(=O)C=CC2=O)CC(C)(C)N1O</smiles><smiles>CN(C)c1cccc2c(NOCCN3C(=O)C=CC3=O)cccc12</smiles>

Maleimide-dansylamide (fluorescence labeling)

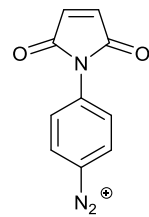

Maleimide-aryl diazonium salts (surface functionalization)

$$
\begin{aligned}
& \text { Maleimide-TEMPO } \\
& \text { (spin labeling) }
\end{aligned}
$$

Maleimide-biotine (affinity labeling)

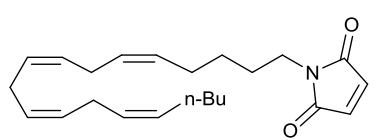

$\mathrm{N}$-Arachidonyl maleimide (monoacylglycerol lipase inhibitor)
Figure 1. Representative examples of commercial maleimide-activated labels. 
We have recently reviewed the current state-of-the-art in the use of maleimides for bioconjugate reactions, ${ }^{4}$ and noticed, however, that only a few scattered comparative studies between the different dienes were reported. Thus selecting the appropriate D-A partner according to the targeted applications is not straightforward, although important theoretical studies have recently been reported on the prediction of rate constants ${ }^{19}$ and factors governing D-A reactions. $^{20,21}$ To address this gap, we report, herein, a systematic comparative study of

maleimide-based D-A strategies in terms of dienes accessibility and stability, reaction rates, as well as cycloadducts isolation and stability. Large differences in reaction rate of D-A suggest that dienes could be used concomitantly in sequential labeling strategies, which should open a new route for the design of multiple conjugate systems.

\section{Results and discussions}

\section{Diene synthesis/accessibility}

Dienes of different natures (linear, cyclic, polycyclic, heterocyclic), which were already reported to react specifically with maleimides in chemoselective ligation, were investigated in this study. Position of the substituent on the diene moiety was selected according to their previous or potential use in ligation experiments (Figure 2).

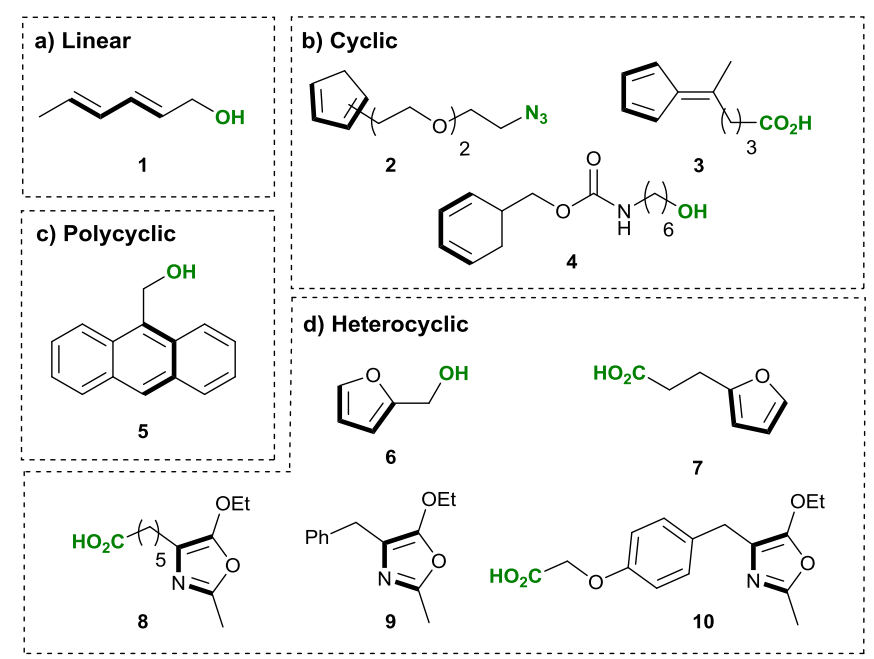

Figure 2. Examples of functionalized dienes used in chemoselective ligations with maleimides.

Dienes $\mathbf{1}^{6,7,11,18,22}$, and $\mathbf{5 - \mathbf { 7 } ^ { 1 1 , 2 3 }}$ are commercially available, while $\mathbf{2},{ }^{15,24}, \mathbf{3}^{25} \mathbf{4}^{12,14}$ and $\mathbf{8 - 9 ^ { 8 }}$ were prepared according to known procedures. In addition, we also report here a novel tyrosinebased oxazole derivative $\mathbf{1 0}$ readily obtained from commercially available tyrosine ethyl ester. First, the cyclopentadiene derivative $\mathbf{2}$ was synthesized in a total of three steps through freshly distilled cyclopentadiene, and tosylate $11,{ }^{26}$ which was obtained in two steps from commercially available 2-[2-(2-chloroethoxy)ethoxy]ethanol (Scheme 1). Monosubstituted cyclopentadiene $\mathbf{2}$ was isolated as a mixture of two inseparable position isomers, 1- and 2cyclopentadiene (ratio $\approx 1: 1$ ), resulting from a well-established fast [1,5]-hydride shift. ${ }^{27}$ Additionally, a fast dimerization of 2 was observed after $36 \mathrm{~h}$ at room temperature (Figures S34S35). Nevertheless, it was relatively stable when stored at -25 ${ }^{\circ} \mathrm{C}$, as less than $10 \%$ dimerization was observed after 9 months of storage. It is also worth noting that Read de Alaniz and Christie observed that cyclopentadiene-modified lysine was stable over the 11-day antibody expression process. ${ }^{17}$ Despite a modest isolated yield of $39 \%$, fulvene 3 requires only one synthetic step from commercially available starting materials. ${ }^{25}$ Furthermore, no isomeric mixture nor chiral centre is present in this structure. In contrast to cyclopentadiene 2, fulvene $\mathbf{3}$ was fully stable for more than 16 days at room temperature (Figure S36). Next, the racemic cyclohexadiene $\mathbf{4}$ was prepared from commercial cyclohex-3-en-1-ylmethanol in a total of 5 synthetic steps and $15 \%$ overall yield (Scheme 1). ${ }^{12,14}$ This cyclic diene was, however, isolated along with $6 \%$ of its aromatized analog, benzyl carbamate (Figure S37), as an inseparable mixture, whatever the purification method used (normal-phase flash chromatography, RP-HPLC or recrystallization in water). These past years, our team reported the preparation of 5-ethoxyoxazole dienes from commercial $\alpha$ hydroxy- or $\alpha$-amino esters for the total synthesis of natural compounds, ${ }^{27-30}$ and for bioconjugation purposes. ${ }^{8,31,32}$ Importantly, the azaphthalimide linkers generated from corresponding 5-ethoxyoxazoles revealed fluorescence behaviors, especially in aqueous media (Figure S2). In the context of modification of peptides, 5-ethoxyoxazole 8 bearing a carboxylic acid function was prepared on the gram scale in a total of six steps and $29 \%$ overall yield. ${ }^{8}$ Interestingly, this compound proved stable for several years at $-25{ }^{\circ} \mathrm{C}$. We postulated that protonation of the nitrogen atom of the oxazole ring by the carboxylic acid moiety preserved 8 against oxidative degradation, such as the formation of the $\mathrm{N}$-oxide derivative which could be observed by HRMS analysis in a sample of degraded 9 (Figure S39). Thus, to support this hypothesis and to find a reliable procedure for long-term storage of 5-alkoxyoxazoles, the model compound $\mathbf{9}$ containing 1 equiv. of acetic acid was also stored at $-25{ }^{\circ} \mathrm{C}$ for nine months. After that time, only $16 \%$ of degradation was observed, while at the same time the model oxazole 9 contained more than $80 \%$ of oxidation product (Figure S38). As a result, a new bioconjugatable analogue $\mathbf{1 0}$ of compound $\mathbf{9}$, bearing a carboxylic acid, was prepared from commercially available ethyl $\mathrm{N}$-acetyl-L-tyrosinate in only three steps and $42 \%$ overall yield. As expected, this diene proved stable since less than $10 \%$ of oxidation was observed after nine months of storage at $-25^{\circ} \mathrm{C}$ (Figure S40). 


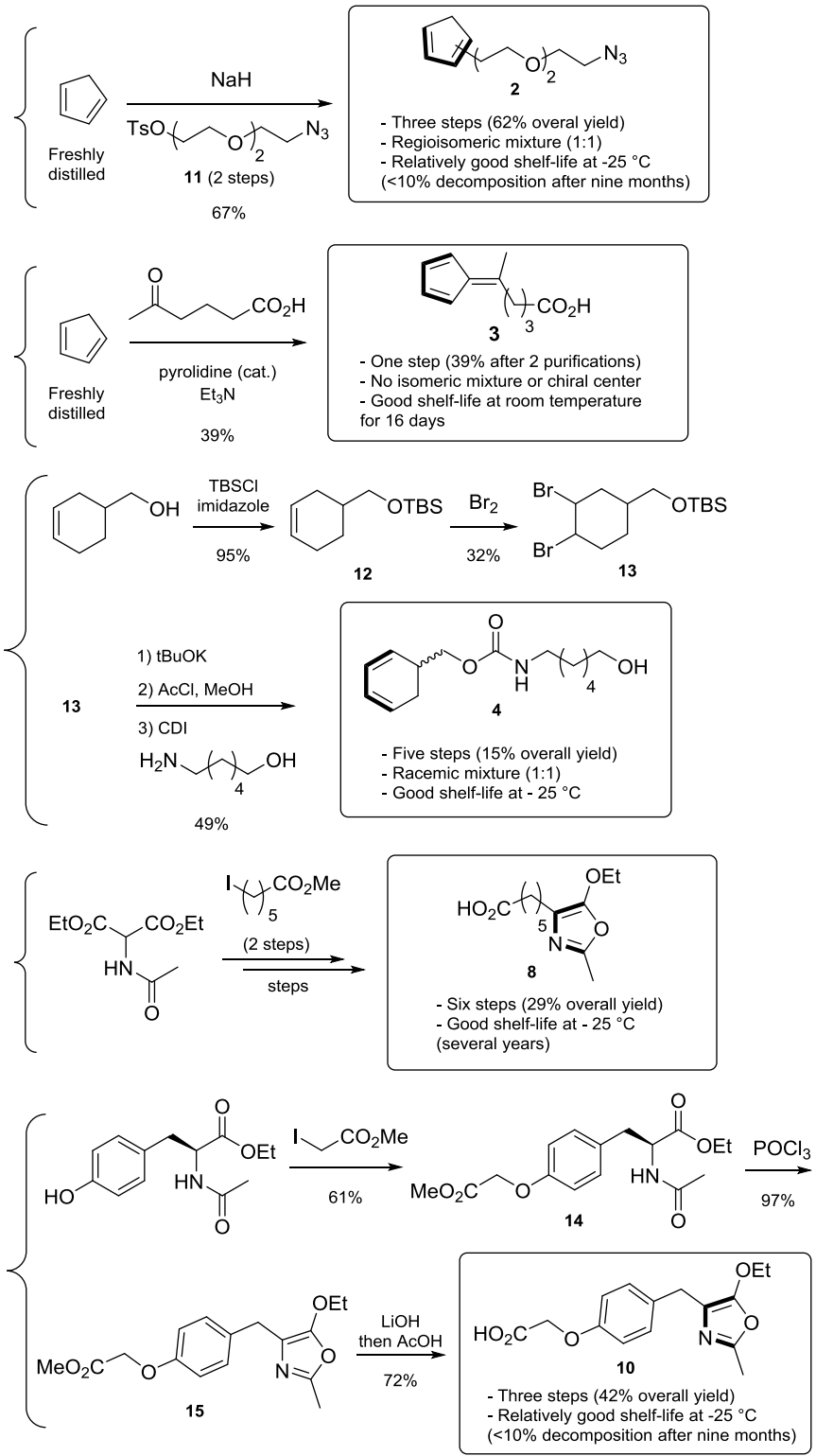

Scheme 1. Syntheses of conjugatable non-commercially available dienes 2-4 and 5-ethoxyoxazoles $\mathbf{8}$ and $\mathbf{1 0}$.

\section{Comparative kinetics study in D-A reactions of dienes with maleimide: towards double labeling strategies}

With dienes 1-10 in hand, their ability to react with maleimides was investigated through the use of a maleimide-based probe 16 whose fluorescence is quenched by a photoinduced electron-transfer (PeT) process, which occurs between the maleimide and the dansyl dye. ${ }^{34,35}$ Then, upon reaction with dienes, the maleimide scaffold is transformed to the corresponding cycloadduct, which leads to a full dansyl fluorescence recovery (Scheme 2).

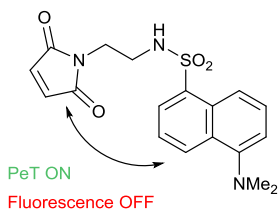

Probe 16
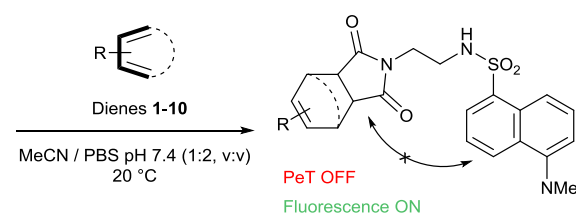

Scheme 2. D-A cycloaddition reactions between dienes $1-10$ and probe $\mathbf{1 6}$ for kinetic comparisons study.

The comparative efficiency of dienes for cycloaddition with maleimides was thus easily assayed by determining the time course of fluorescence intensity enhancement over a 60minute time scale. Results are summarized in Figure 3. Dienes from each class of compounds were also subject to RP-HPLC analysis at $\mathrm{t}=10$ minutes for cyclopentadiene $\mathbf{2}$, and $\mathrm{t}=60$ minutes for other dienes to confirm fluorescence recovery assays (Table 1). The cyclopentadiene derivative $\mathbf{2}$ exhibited by far the highest rate of fluorescence enhancement. After 10 min of reaction, maleimide $\mathbf{1 6}$ was entirely consumed, which was also confirmed by RP-HPLC analysis (Figure S10). A calibration curve that correlates the fluorescence intensity to the cycloadduct concentration enabled us to determine the second order kinetic rate constant $k_{2}=6.50 \pm 0.02 \mathrm{M}^{-1} \cdot \mathrm{s}^{-1}$ in MeCN/PBS pH 7.4 (1:2, v:v) at $\mathrm{T}=20{ }^{\circ} \mathrm{C}$ (Figures S19-S21). While results obtained by fluorescence experiments matched well with the ones determined by RP-HPLC, the cycloaddition with fulvene and anthracene are the exception. In fact, no fluorescence intensity change could be detected after 60 minutes while cycloadducts formation was observed by RPHPLC. This result from the fact that fulvene and anthracene absorb the incident UV light, which is confirmed by their absorption profiles that exhibit a band at $330 \mathrm{~nm}$, preventing
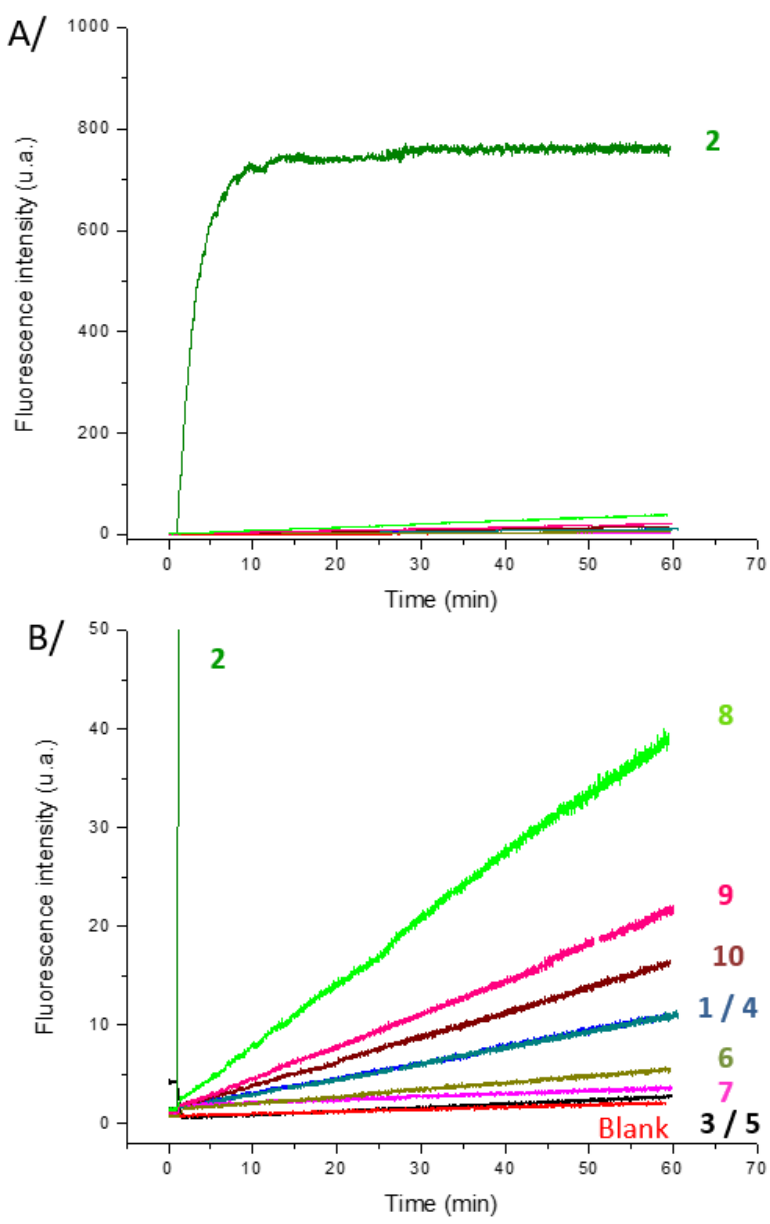

thus the excitation of the dansyl dye (Figure S2). 
Figure 3. A) Time-dependent fluorescence intensity increase of dansyl-based probe 16 (1 mM, 1 equiv.) in the presence of dienes 1-10 (5 mM, 5 equiv.) in $\mathrm{nm}$. B) Enlarged view of Figure $3 \mathrm{~A}$ ).

Of note their corresponding cycloadducts do not absorb at 330 $\mathrm{nm}$ (Figures S5-S8). Moderate to low conversions were observed with the other dienes. A conversion of $39 \%$ was reached after 60 minutes of reaction with fulvene 3 , the second fastest diene. Then, 5-ethoxyxazoles and anthracene have shown to react more slowly, with only 17,13 and $11 \%$ of conversion for compounds $\mathbf{8}, \mathbf{5}$ and $\mathbf{9}$, respectively, after 60 minutes. Finally, cyclohexadiene 4, trans-trans-2,4-hexadiene 1, and furans 6-7 gave even lower kinetics, with less than $5 \%$ conversion after 60 minutes. The same trend was observed with a lower probe concentration (50 $\mu \mathrm{M}$, Figure S3). Following these results, $k_{2}$ was determined for several of these dienes. Due to their apparent slow kinetics, these values were determined by RP-HPLC analysis from calibration curves (Figures S22-S25), and results are summarized in Table 1.

Table 1 Kinetic Data for the D-A Reaction in aqueous media. ${ }^{a}$

\begin{tabular}{ccc}
\hline Diene & \% conv. (min) & $\boldsymbol{k}_{\mathbf{2}}\left(\mathrm{M}^{-1} \cdot \mathrm{s}^{-1}\right)$ \\
\hline $\mathbf{1}$ & $1(60)$ & $(8.9 \pm 0.7) * 10^{-4}$ \\
$\mathbf{2}$ & $>99(10)$ & $6.50 \pm 0.02$ \\
$\mathbf{3}$ & $39(60)$ & $0.15 \pm 0.01$ \\
$\mathbf{4}$ & $4(60)$ & n.d. \\
$\mathbf{5}$ & $13(60)$ & n.d. \\
$\mathbf{6}$ & $<1(60)$ & $(8.9 \pm 0.1)^{*} 10^{-4}$ \\
$\mathbf{7}$ & $<1(60)$ & n.d. \\
$\mathbf{8}$ & $17(60)$ & $(1.2 \pm 0.4) * 10^{-2}$ \\
$\mathbf{9}$ & $11(60)$ & $(5.1 \pm 0.3) * 10^{-3}$ \\
$\mathbf{1 0}$ & n.d. & n.d. \\
\hline
\end{tabular}

${ }^{a}$ Reaction in MeCN/PBS pH $7.4(1: 2, \mathrm{v}: \mathrm{v})$ at $20^{\circ} \mathrm{C}$ monitored by RP-HPLC $(\lambda=330$ $\mathrm{nm}$ ), except for diene $\mathbf{2}$ where fluorescence spectroscopy was used. ${ }^{b}$ n.d.: not determined.
The large difference in reaction rates observed between the cyclopentadiene and other dienes, such as 5-ethoxyoxazoles, prompted us to investigate their combined use in the prospect, for example, of developing one-pot double labeling strategies potentially useful for biological applications, or for the design of (hetero)multifunctional cross-linking reagents. ${ }^{3,36-39}$ Such an approach generally relies on the use of mutually orthogonal chemoselective ligations, ${ }^{40}$ or the catalytic activation of one of the two ligations when they share a common chemical function such as copper-catalyzed alkyne azide cycloadditions (CuAAC) used in the combination of strain-promoted alkyne azide cycloaddition (SPAAC). ${ }^{41}$ In the present study, since one of the maleimide-based reagent was common to both chemical ligations, we questioned whether the selectivity for one of the two dienes could be controlled by their large kinetic difference. To verify this hypothesis, a stoichiometric mixture of the two sufficiently kinetically different dienes, namely cyclopentadiene 2/oxazole 8 ( 1 equiv. each), was treated with maleimide 16 (1 equiv.) at $25{ }^{\circ} \mathrm{C}$ and stirred for $1 \mathrm{~h}$ (STEP 1, Figure 4A), before adding the coumarinbased maleimide $\mathbf{M C}^{42}$ (5 equiv.) (STEP 2). This one-pot 2 steps protocol was followed by RP-HPLC analysis. Figure 4B shows relevant enlarged views of RP-HPLC chromatograms recorded at $330 \mathrm{~nm}$ ( $\lambda_{\mathrm{abs}}$ of dansyl) in order to simplify chromatograms and focus on the selectivity outcome of the first step. Full-view data also determined at $254 \mathrm{~nm}$ are also available in the ESI. The first step led exclusively to cycloadduct $\mathbf{1 7 b}$, observed as a mixture of 4 distinguishable isomers. Indeed, the formation of the competitive cycloadduct or azaphthalimide resulting from the reaction of the oxazole $\mathbf{8}$ with maleimide $\mathbf{1 6}$ was not observed (STEP 1 versus CONTROL, Figure 4B). Then, the addition of the second maleimide (MC) to the reaction mixture provided mostly the corresponding azaphthalimide $\mathbf{1 8}$ after 24 $h$ (STEP 2). The aromatization of the oxabicycle intermediate under "neutral conditions", we previously observed in acidic conditions, ${ }^{8}$ and ending up in an irreversible rearomatization reaction process, is presumably promoted by the presence of an internal proton source thanks to the carboxylic acid function, combined with a long reaction time. 


\section{ARTICLE}

A/
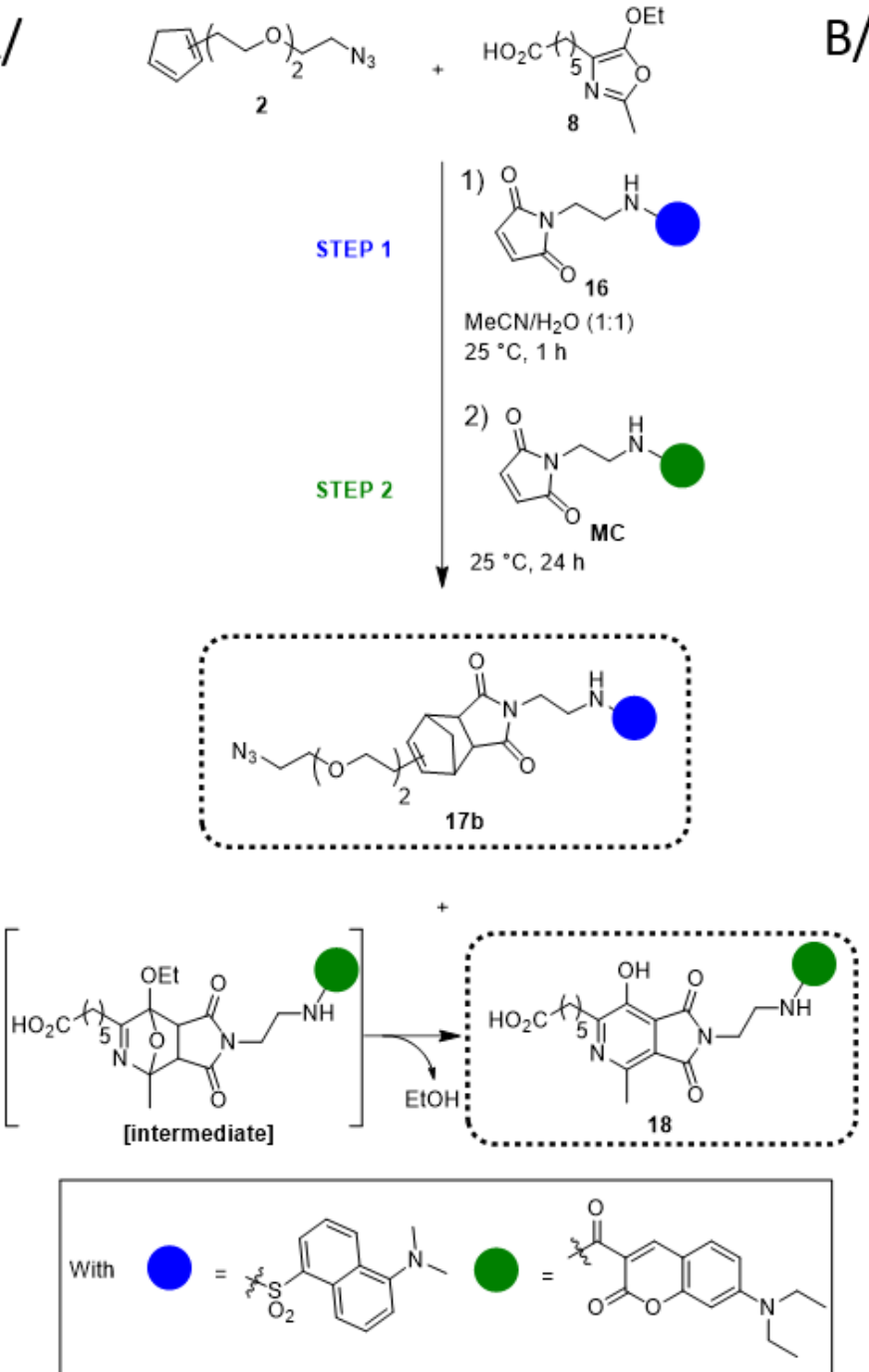

B/
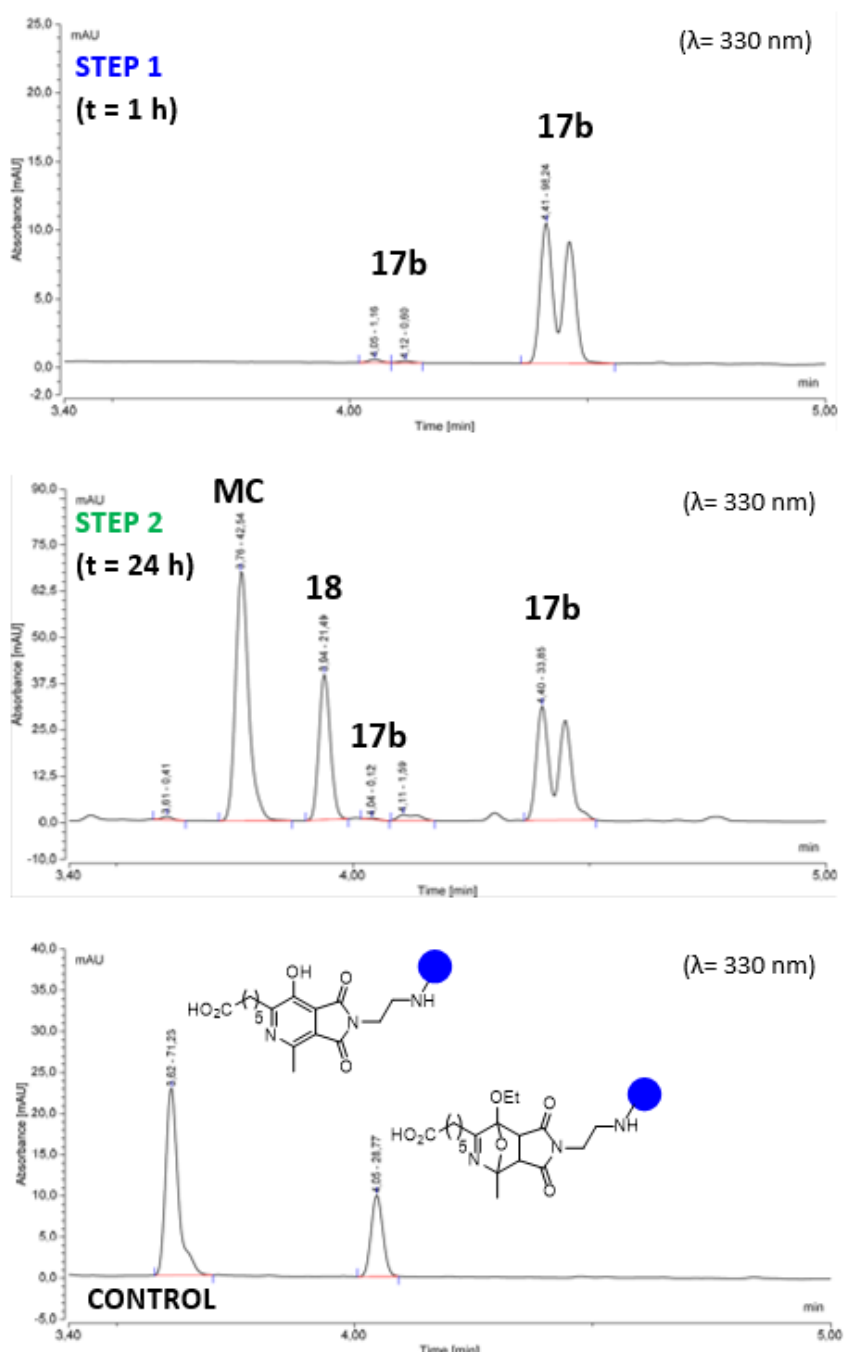
Figure 4. (A) Sequential labeling experiment from a stoichiometric mixture of cyclopentadiene $\mathbf{2}$ and oxazole $\mathbf{8}$ followed by the successive addition of maleimide $\mathbf{1 6}$ (1
equiv.) and MC (5 equiv.). (B) RP-HPLC monitoring of the one-pot two step procedure (STEP 1, STEP 2 ) and references of possible by-products resulting from the equiv.) and MC (5 equiv.). (B) RP-HPLC monitoring of the one-pot two step procedure (STEP 1, STEP 2) and references of possible by-products resulting from the
reaction
(CONTROL).

This experiment clearly illustrates that the kinetics difference between the D-A reactions could be exploited to achieve sequential bioconjugate reactions and to offset the need for chemoselectivity between the reactive functions. Moreover, a perfect chemical compatibility between $\mathbf{2}$ and $\mathbf{8}$ was observed in our study, which made very convenient this one-pot procedure.

Isolation and stability of conjugates, evaluation of isomer amounts.
Next, an enantiomerically pure maleimide partner 19 , namely (R)-1-(1-phenylethyl)-1H-pyrrole-2,5-dione, was selected as dienophile partner to study first how its chirality could impact HPLC analyses of isolated cycloadducts in terms of number of isomers, while avoiding issues related to the short half-life of chiral biomolecules for the stability study in blood plasma. In fact, the formation of uncontrolled stereogenic centers during the cycloaddition process combined to those already present in biomolecules, may lead to the formation of multiple isomers. This may complicate the reaction monitoring, as well as the bioconjugate isolation and characterization in particular with low-molecular weight conjugates (a few kDa). ${ }^{5,13,43}$ 
Besides, isomeric products may display significant difference in biological, or physicochemical properties. ${ }^{44}$ Accordingly, products 20-26 were prepared in moderate to good yields from corresponding dienes $\mathbf{1 - 6}$ and $\mathbf{8}$ in a solution of THF/water mixture, whereas one equivalent of trifluoroacetic acid was also added to the reaction mixture for compound 8 to furnish the corresponding the fluorescent azaphthalimide $\mathbf{2 6}$ (Scheme 3). Multiple isomers were observed by ${ }^{1} \mathrm{H}$ NMR analysis for all cycloadducts 20-25, with the exception of azaphthalimide $\mathbf{2 6}$ whose stereogenic centers were suppressed by the aromatization step. Moreover, a mixture of two isomers was observed by RP-HPLC only for cycloadducts 21 and $\mathbf{2 5}$ generated from the cyclopentadiene and furan derivatives, respectively. This set of experiments clearly illustrates the advantage of the oxazole- based bioconjugate reaction for low molecular weight bioconjugates, since, provided the occurring further aromatization process, this is the only reaction yielding only one isomer (either regio or stereoisomer). Consequently, this is the only diene avoiding the formation of heterogeneous conjugates likely to have different properties.

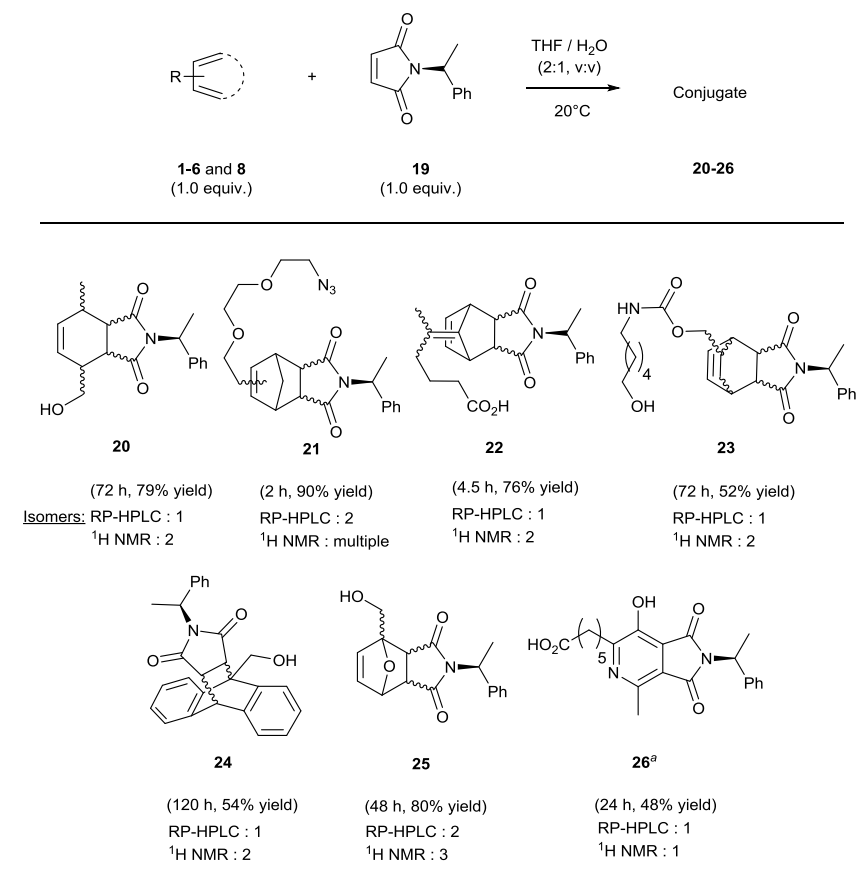

Scheme 3. Conjugates 20-26 obtained from Diels-Alder reactions of dienes $\mathbf{1 - 6}$ and $\mathbf{8}$ with maleimide $\mathbf{1 9}$, and experimentally identified isomers. ${ }^{a}$ Prepared in the presence of TFA ( 1 equiv.).

The stability of the conjugate adduct is important to ensure that the two ligated units will not prematurely dissociate in biological media. In fact, the reversible character of the D-A reaction is closely associated with the nature of the dienedienophile pair. Moreover, imide-containing cycloadducts may also be subject to hydrolysis under physiological conditions, as reported for example for some thiosuccinimides resulting from the addition of biothiols to maleimides. ${ }^{4,45-48}$ Accordingly, the reversibility, and more generally the stability of imide-based cycloadducts obtained from different classes of dienes was next investigated. It should be stressed that the oxazole strategy leads directly to the aromatized azaphthalimide scaffold under acidic conditions (the oxabicyclic intermediate being generally unstable during chromatographic purification, but prone to aromatization), and therefore could not be subjected to a retro-D-A process. The reversible behaviour of cycloadducts 20-25 was investigated at $37{ }^{\circ} \mathrm{C}$, in a iPrOH/PBS pH 7.4 (1:1) solution containing 10 equiv. of $\mathrm{N}$-acetylcysteine (NAC) as a fast maleimide-trapping agent (Figure S49). ${ }^{49}$ Formation of the thiol Michael adduct 27, resulting from thioMichael addition reaction between NAC and 19 , will be observed only if rD-A reactions occurred (Scheme 4). Thioether 27 was synthesized, characterized and used as reference for this study. This compound was found to be fully stable after 24 $\mathrm{h}$ in iPrOH/PBS pH $7.4(1: 1), 37{ }^{\circ} \mathrm{C}$. Stability experiments revealed that all cycloadducts were stable for $24 \mathrm{~h}$ under physiological conditions, except oxabicycle 25, for which thiol Michael adduct was observed in noticeable amount $(30 \%$, Figure S55) which was consistent with recent studies. ${ }^{50}$ Of note, the azaphthalimide $\mathbf{2 6}$ was stable under these reaction conditions.

Finally, the chemical and enzymatic stability of conjugates were investigated by incubating compounds 20-26 in human blood plasma (HBP) at $37{ }^{\circ} \mathrm{C}$ for $24 \mathrm{~h} .{ }^{51} \mathrm{HBP}$ is composed of proteins ( $8 \%)$, organic compounds (1\%), and mineral salts (1\%). After $24 \mathrm{~h}$ incubation, HPLC-MS analyses showed that most of cycloadducts appeared to be stable, except compounds $\mathbf{2 0}$ and $\mathbf{2 6}$ for which monohydrolysis of the corresponding imide was observed in about 35 and 4\%, respectively, along with presumably epimerization for $\mathbf{2 0}$ and traces of $\mathrm{N}$-oxidation for 26. A plausible explanation for this is that bridged ring systems in 21-25 provide additional steric hindrances in the vicinity of the imide function protecting this imide against hydrolysis, compared to simply fused ring scaffolds $\mathbf{2 0}$ and $\mathbf{2 6}$. Of note, degradation products of $\mathbf{2 0}$ and $\mathbf{2 6}$ maintain nevertheless a covalent linkage between the two conjugation partners through the remaining amide bond.

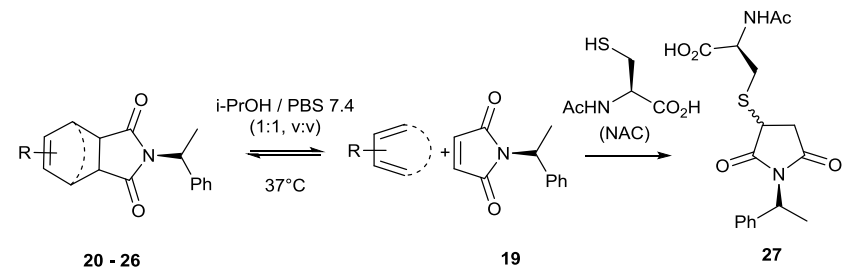

Scheme 4. rD-A study in the presence of an excess of NAC as fast maleimidetrapping agent.

\section{Conclusions}

Herein is reported a comparative study of a collection of (hetero)diene systems involved in maleimide-based cycloaddition reactions that had proved useful applications for chemoselective ligation. It was observed that noncommercially available dienes were stable for several months at $-25{ }^{\circ} \mathrm{C}$ or days at room temperature, and that 5- 
alkoxyoxazoles required stabilization by an internal or external source of protons to protect them from long-term air $\mathrm{N}$ oxidation. From this observation, it resulted the preparation of a novel and storable conjugable tyrosine-based oxazole, obtained within three steps and a good overall yield. In addition, while cyclopentadiene proved particularly unstable, a recent study reported in situ deprotection of cyclopentadienes to overcome their important lack of stability. ${ }^{52}$

With regard to the kinetic study, it was established that cyclopentadiene conjugate reacts with maleimides between one and three orders of magnitude faster than the other diene families. The second order kinetic rate constants were found to be between $10^{-4}$ and $10 \mathrm{M}^{-1} \cdot \mathrm{s}^{-1}$, comparatively, the Staudinger ligation has a rate constant of $10^{-3} \mathrm{M}^{-1} \cdot \mathrm{s}^{-1} \cdot{ }^{53}$ Dienes may be ranked in descending order in terms of their reactivity as follows: cyclopentadiene, fulvene, 5-ethoxyoxazoles family and anthracene, cyclic and linear dienes and finally furan based derivatives. Such difference was leveraged in a proof-ofconcept for sequential labeling strategy. The chemical compatibility observed between the cyclopentadiene and 5ethoxyoxazole could further be exploited in the design of novel heterobifunctional cross-linking reagents with useful applications in bioconjugation and materials science.

The formation of multiple isomeric products was observed with all dienes, except for oxazole whose aromatization step leads to the formation of a single product, with unique fluorescent properties.

In addition, stability experiments revealed that only furan cycloadduct underwent cleavage through a rD-A process leading to the dissociation of the reaction partners under physiological conditions, whereas unbridged fused systems were mainly subject to monohydrolysis in HBP.

To conclude, since none of the dienes combines all the appropriate aforementioned properties (i.e. starting material commercially available and indefinitely stable at room temperature, ligation rate faster than $1 \mathrm{M}^{-1} \cdot \mathrm{s}^{-1}$, single isomeric product, etc...), we hope this article will be a useful guide for the reader in choosing the most convenient diene according his targeted application and the (bio)molecular system which will be involved, in particular with regard to the accessibility/availability of dienes, reaction rates, products isolation and stability or fluorescence properties.

\section{Conflicts of interest}

There are no conflicts to declare.

\section{Experimental}

\section{General}

All chemicals were used as received from commercial sources without further purification, except cyclopentadiene which was freshly distilled prior to use. Solvents, unless otherwise stated, were purchased in reagent grade or HPLC grade and used as received. PBS $(\mathrm{pH} 7.4,0.1 \mathrm{M})$ and aq. mobile phases for HPLC were prepared with water that was purified by means of a MilliQ system (purified to $18.2 \mathrm{M} \Omega \mathrm{cm}$ ). For Diels-Alder reaction in aqueous media, MilliQ $\mathrm{H}_{2} \mathrm{O}$ was used in the solvents system. Human blood plasma (HBP) was furnished by the Centre Hospitalier Universitaire de Rouen and was collected under medical conditions and supervisions from unknown donors. (CAUTION! HBP is a biological substance that must be handled with care by trained personnel. Vials, needles, pipettes, etc. must be considered and treated as biological wastes). All reactions were monitored by thin layer chromatography (TLC) and/or RP-HPLC. TLC were carried out on Merck DC Kieselgel 60 F-254 aluminum sheets. Visualization of spots was performed under a UV lamp at $\lambda=254$ or $365 \mathrm{~nm}$, and/or staining with a $\mathrm{KMnO}_{4}$ solution $/ \mathrm{K}_{2} \mathrm{CO}_{3}+5 \% \mathrm{NaOH}$, developed with heat. Flash column chromatography purifications were performed manually on silica gel (40-63 $\mu \mathrm{M})$ under pressurized air flow.

\section{Instruments and methods}

System A: RP-HPLC analyses were performed with a Thermo Scientific Ultimate ${ }^{\circledR} 3000$ RS instrument, equipped with a diode array detector (DAD-3000RS) and temperature of the column compartment was fixed at $25{ }^{\circ} \mathrm{C}$. A Thermo Fisher Hypersyl GOLD ${ }^{\circledR}$ column $(1.9 \mu \mathrm{m}, 2.1 \times 50 \mathrm{~mm})$ was used with a binary solvent system composed of $\mathrm{MeCN}$ and $0.1 \%$ aq. formic acid (aq. FA, pH 2) as eluents (linear gradient from 5 to $100 \% \mathrm{MeCN}$ over $6 \mathrm{~min} ; 100 \% \mathrm{MeCN}$ for $1.5 \mathrm{~min}$; linear gradient from 100 to $5 \% \mathrm{MeCN}$ over $1.5 \mathrm{~min}$; $5 \% \mathrm{MeCN}$ for 2 $\min$ ) at a flow rate of $0.600 \mathrm{~mL} / \mathrm{min}$. System B: RP-HPLC analyses were performed with a Thermo Scientific Ultimate ${ }^{\circledR}$ 3000 RS instrument, equipped with a diode array detector (DAD-3000RS) and temperature of the column compartment was fixed at $25{ }^{\circ} \mathrm{C}$. An Agilent SB-C18 ${ }^{\circledR}$ column $(1.8 \mu \mathrm{m}, 2.1 \times$ $50 \mathrm{~mm}$ ), equipped with a Phenomenex $\mathrm{AJO}-9000^{\circledR} \mathrm{C} 18$ precolumn, was used with a binary solvent system composed of MeCN and $0.1 \%$ aq. formic acid (aq. FA, pH 2) as eluents (linear gradient from 5 to $100 \%$ MeCN over $6 \mathrm{~min} ; 100 \% \mathrm{MeCN}$ for 1.5 min; linear gradient from 100 to $5 \% \mathrm{MeCN}$ over $1.5 \mathrm{~min} ; 5 \%$ MeCN for $2 \mathrm{~min}$ ) at a flow rate of $0.600 \mathrm{~mL} / \mathrm{min}$. System C: RPHPLC-MS analysis were performed on a Agilent 1200 Series $^{\circledR}$ and Bruker HCT ultra ${ }^{\circledR}$ instruments, equipped with a Thermo Fisher Accucore ${ }^{\circledR}$ C18 column $(2.6 \mu \mathrm{M}, 2.1 \times 150 \mathrm{~mm})$. Temperature was maintained to $22{ }^{\circ} \mathrm{C}$. Injection volume was 4 $\mu \mathrm{L}$. UV detector (set at $254 \mathrm{~nm}$ ) was coupled with a lowresolution MS detector (ESI/ion trap). Solvent system was composed of MeCN and $0.1 \%$ aq. formic acid (aq. FA, pH 2) as eluents ( $5 \% \mathrm{MeCN}$ for $1 \mathrm{~min}$, linear gradient from 5 to $100 \%$ MeCN over $14 \mathrm{~min} ; 100 \% \mathrm{MeCN}$ for $3 \mathrm{~min}$; linear gradient from 100 to $5 \%$ MeCN over $1 \mathrm{~min}$; $5 \% \mathrm{MeCN}$ for $11 \mathrm{~min}$ ) at a flow rate of $0.300 \mathrm{~mL} / \mathrm{min}$. System D: Semi-preparative RP-HPLC were performed with a Interchim Puriflash ${ }^{\circledR} 4250$ instument equipped with a UV-visible detector, and a Hypersil Gold ${ }^{\circledR}$ column $(5 \mu \mathrm{m}, 250 \times 20 \mathrm{~mm}$ ) with $\mathrm{MeCN}$ and $0.1 \%$ aq. FA as eluents ( $5 \% \mathrm{MeCN}$ for $5 \mathrm{~min}, 5-100 \% \mathrm{MeCN}$ for $48 \mathrm{~min}$ ) at a flow rate of $20 \mathrm{~mL} / \mathrm{min}$. 
High Resolution Mass spectrometry (HRMS) was performed using a Waters Micromass LCT Premier $\mathrm{XE}^{\circledR}$ equipped with an orthogonal acceleration time-of-flight (oa-TOF) and an electrospray source in positive or negative mode.

${ }^{1} \mathrm{H},{ }^{13} \mathrm{C}$ spectra were recorded on $300 \mathrm{MHz}$ Bruker FT-NMR machine operating at ambient probe temperature. The solvent resonance was used as the internal standard for ${ }^{1} \mathrm{H}-\mathrm{NMR}$ (chloroform-d at $7.26 \mathrm{ppm}$; acetonitrile-d3 at $1.94 \mathrm{ppm}$; acetone-d6 at $2.05 \mathrm{ppm}$; methanol-d4 at $3.31 \mathrm{ppm}$; DMSO-d6 at 2.50) and ${ }^{13} \mathrm{C}-\mathrm{NMR}$ (chloroform-d at $77.0 \mathrm{ppm}$; acetonitriled3 at $1.3 \mathrm{ppm}$; acetone-d6 at $29.8 \mathrm{ppm}$; methanol-d4 at 49.0 ppm ; DMSO-d6 at 39.5). Chemical shift $(\delta)$ were quoted in parts per million (ppm). Coupling constants $(J)$ were quoted in Hertz $(\mathrm{Hz})$. The following abbreviations were used to give the multiplicity of the NMR signals: s: singlet, bs: broad singlet, $d$ : doublet, t: triplet, dd: doublet of doublet...

Fluorescence spectroscopic studies (emission/excitation spectra and time course) were performed on a Varian Cary Eclipse $^{\circledR}$ spectrophotometer using a quartz fluorescence cell (Hellma, 104F-QS, $10 \times 4 \mathrm{~mm}$, pathlength $10 \mathrm{~mm}$, chamber volume $3.5 \mathrm{~mL}$ or $1.4 \mathrm{~mL}$ ). Excitation/emission spectra were recorded at $20^{\circ} \mathrm{C}(330 / 560 \mathrm{~nm}$, excitation and emission filters: auto, excitation and emission slit: $5 \mathrm{~nm}$ or $10 \mathrm{~nm}$ ). UV-Vis spectroscopy was performed on a Agilent Cary $60 \mathrm{UV}^{-V i s}{ }^{\circledR}$ at $20^{\circ} \mathrm{C}$.

For conjugates stabilities in $\mathrm{HBP}$, centrifugations were performed with a VWR MicroStar $12^{\circledR}$ at 11.000 rotations/min for $30 \mathrm{~min}$.

\section{Synthesis}

\section{Diene synthesis}

\section{Synthesis of the cyclopentadiene (2)}

Tosylate-azide (11). To a solution of 2-(2-(2azidoethoxy)ethoxy)ethanol $^{54}(2.5 \mathrm{~g}, 14.3 \mathrm{mmol}, 2$ equiv.) in dry acetonitrile $(20 \mathrm{~mL})$, were successively added $\mathrm{Et}_{3} \mathrm{~N}(8.47$ $\mathrm{mL}, 62.7 \mathrm{mmol}, 4.4$ equiv.) and $\mathrm{TsCl}(1.36 \mathrm{~g}, 7.1 \mathrm{mmol}, 1.0$ equiv.). The reaction mixture was stirred at room temperature for $2 \mathrm{~h}$. After completion, a solution of saturated aq. $\mathrm{NH}_{4} \mathrm{OH}$ $(50 \mathrm{~mL})$ was poured onto the reaction mixture, followed by brine $(25 \mathrm{~mL})$. The aqueous layer was extracted with EtOAc (3 $\times 50 \mathrm{~mL}$ ). Combined organic layers were washed with brine (50 $\mathrm{mL}$ ), dried over $\mathrm{MgSO}_{4}$, and evaporated under vacuum. The crude product was purified by flash-column chromatography (silica gel, cyclohexane/EtOAc as gradient from 100:0 to 90:10, $\mathrm{v} / \mathrm{v}$ ) to provide the product $(2.32 \mathrm{~g}, 7.03 \mathrm{mmol}, 99 \%$ yield) as a yellow oil. The following ${ }^{1} \mathrm{H}$ NMR analysis was in accordance with literature data. ${ }^{25} \mathrm{H}$ NMR $\left(300 \mathrm{MHz}, \mathrm{CDCl}_{3}\right): \delta 7.82-7.76$ $(\mathrm{m}, 2 \mathrm{H}), 7.37-7.30(\mathrm{~m}, 2 \mathrm{H}), 4.19-4.13(\mathrm{~m}, 2 \mathrm{H}), 3.73-3.66$ $(\mathrm{m}, 2 \mathrm{H}), 3.66-3.61(\mathrm{~m}, 2 \mathrm{H}), 3.60(\mathrm{~s}, 4 \mathrm{H}), 3.40-3.33(\mathrm{~m}, 2 \mathrm{H})$, $2.44(\mathrm{~s}, 3 \mathrm{H})$.

Cyclopentadiene (2). To a solution of freshly distilled cyclopentadiene ( $380 \mu \mathrm{L}, 4.56 \mathrm{mmol}, 3$ equiv.) in dry THF $(5 \mathrm{~mL})$ cooled at $0{ }^{\circ} \mathrm{C}$, under argon atmosphere, was added sodium hydride (60\% w/w in mineral oil, $182 \mathrm{mg}, 4.56 \mathrm{mmol}, 3$ equiv.) in one portion into the reaction mixture, which became rapidly dark red. After $15 \mathrm{~min}$, the homogenous mixture was cooled at $-78{ }^{\circ} \mathrm{C}$, and a solution of 2-(2-(2-azidoethoxy)ethoxy)ethyl 4methylbenzenesulfonate 11 (500 $\mathrm{mg}, 1.52 \mathrm{mmol}, 1$ equiv.) in dry THF $(5 \mathrm{~mL})$ was introduced dropwise to the mixture. After stirring at $-78^{\circ} \mathrm{C}$ for $1 \mathrm{~h}$, the reaction mixture was allowed to warm to $0{ }^{\circ} \mathrm{C}$ over $2 \mathrm{~h}$. After completion, the mixture was filtered on a Celite ${ }^{\circledR}$ plug and the precipitate was washed four times with EtOAC and DCM. The filtrate was concentrated under vacuum to give a brown solid, which was purified by flash-column chromatography (silica gel, cyclohexane/EtOAc as gradient from 100:0 to $90: 10, v / v)$ to afford 1-(2-(2-(2azidoethoxy)ethoxy)ethyl)cyclopenta-1,3-diene $2(227 \mathrm{mg}$, $0.95 \mathrm{mmol}, 67 \%$ yield) as a light yellow oil. IR (neat): 2924, 2865, 2099, 1745, 1709, 1442, 1346, 1284, 1110, 928, 811. Two inseparable isomers were observed by NMR in a 1:1 ratio and are reported below: ${ }^{1} \mathrm{H} \mathrm{NMR}\left(300 \mathrm{MHz} \mathrm{CDCl}_{3}\right): \delta 6.44$ (ddq, $J=12.0,3.1,1.5 \mathrm{~Hz}, 3 \mathrm{H}$ ), 6.27 (ddd, $J=5.3,2.7,1.4 \mathrm{~Hz}$, $1 \mathrm{H}), 6.24-6.19(\mathrm{~m}, 1 \mathrm{H}), 6.11-6.05(\mathrm{~m}, 1 \mathrm{H}), 3.71-3.59(\mathrm{~m}$, $16 \mathrm{H}), 3.38(\mathrm{t}, J=5.0 \mathrm{~Hz}, 4 \mathrm{H}), 2.94(\mathrm{dtd}, J=4.2,2.9,1.5 \mathrm{~Hz}, 4 \mathrm{H})$, 2.94 (dtd, $J=4.2,2.9,1.5 \mathrm{~Hz}, 4 \mathrm{H}), 2.75-2.63(\mathrm{~m}, 4 \mathrm{H}), 1.66(\mathrm{~s}$, $1 \mathrm{H}), 1.34-1.18(\mathrm{~m}, 1 \mathrm{H}) .{ }^{13} \mathrm{C} N M R\left(75 \mathrm{MHz}, \mathrm{CDCl}_{3}\right): \delta 146.0$, $143.6,134.7,133.8,132.4,131.1,127.7,127.4,77.5,77.1$, 76.7, 71.3, 70.8, 70.7, 70.3, 70.2, 70.1, 50.7, 43.8, 41.4, 31.0, 30.3. HRMS (ESI+) Calculated for $\mathrm{C}_{11} \mathrm{H}_{21} \mathrm{~N}_{4} \mathrm{O}_{2}[\mathrm{M}+\mathrm{H}]^{+}$: 241.1665 ; found : 241.1664. HPLC System $A(\lambda=254 \mathrm{~nm}) t_{\mathrm{R}}=$ $4.24 \mathrm{~min}$.

\section{Synthesis of the cyclohexadiene (3).}

tert-Butyl(cyclohex-3-en-1-ylmethoxy)dimethylsilane (12). To a solution of cyclohex-3-en-1-ylmethanol (2.00 g, 17.8 mmol, 1 equiv.) in dry DMF ( $8 \mathrm{~mL})$ under argon atmosphere, was added imidazole (2.43 g, $35.7 \mathrm{mmol}, 2$ equiv.). The reaction mixture was cooled to $0{ }^{\circ} \mathrm{C}$ and then, tertbutyldimethylsilyl chloride ( $3.23 \mathrm{~g}, 21.4 \mathrm{mmol}, 1.2$ equiv.) was added. After $5 \mathrm{~min}$, the reaction was allowed to warm to room temperature for and was stirred for $1 \mathrm{~h}$. After completion, the reaction was quenched with water $(80 \mathrm{~mL})$ and the resulting mixture was extracted with $\mathrm{Et}_{2} \mathrm{O}(3 \times 40 \mathrm{~mL})$. Combined organic layer was washed with water $(50 \mathrm{~mL})$ and brine $(50$ $\mathrm{mL}$ ) and was dried over $\mathrm{MgSO}_{4}$, and evaporated under vacuum. The crude product was purified by flash-column chromatography (silica gel, cyclohexane) to provide the title compound ( $3.65 \mathrm{~g}, 16.1 \mathrm{mmol}, 95 \%$ yield) as a colorless liquid. The following ${ }^{1} \mathrm{H}$ NMR analysis was in accordance with literature data. ${ }^{14}{ }^{1} \mathrm{H}$ NMR $\left(300 \mathrm{MHz}, \mathrm{CDCl}_{3}\right): \delta 5.67(\mathrm{~d}, J=2.2$ $\mathrm{Hz}, 2 \mathrm{H}), 3.48(\mathrm{~d}, J=1.9 \mathrm{~Hz}, 1 \mathrm{H}), 3.49(\mathrm{~d}, J=1.9 \mathrm{~Hz}, 1 \mathrm{H}), 2.12-$ $2.00(\mathrm{~m}, 3 \mathrm{H}), 1.85-1.63(\mathrm{~m}, 3 \mathrm{H}), 1.34-1.15(\mathrm{~m}, 1 \mathrm{H}), 0.90(\mathrm{~s}$, $9 \mathrm{H}), 0.04(\mathrm{~s}, 6 \mathrm{H})$.

\section{tert-Butyl((3,4-dibromocyclohexyl)methoxy)dimethyl-}

silane (13). To a solution of tert-butyl(cyclohex-3-en-1ylmethoxy)dimethylsilane 11 (500 mg, $2.2 \mathrm{mmol}$, 1 equiv.) in dry DCM $(5 \mathrm{~mL})$, cooled to $0{ }^{\circ} \mathrm{C}$ under argon atmosphere, was added $\mathrm{NaHCO}_{3}(185 \mathrm{mg}, 2.2 \mathrm{mmol}, 1.0$ equiv.). A solution of bromine ( $0.12 \mathrm{~mL} \mathrm{~g}, 2.42 \mathrm{mmol}, 1.2$ equiv.) in DCM ( $3 \mathrm{~mL}$ ) was added dropwise at $0{ }^{\circ} \mathrm{C}$. The reaction mixture was stirred at 0 
${ }^{\circ} \mathrm{C}$ for $2 \mathrm{~h}$ after the addition of bromine solution. Then, reaction was quenched with a mixture of sat. aq. $\mathrm{Na}_{2} \mathrm{~S}_{2} \mathrm{O}_{3}$ and sat. aq. $\mathrm{Na}_{2} \mathrm{CO}_{3}(15 \mathrm{~mL}, 1: 1, \mathrm{v} / \mathrm{v})$. The resulting mixture was extracted with EtOAc $(3 \times 10 \mathrm{~mL})$. Combined organic layer dried over $\mathrm{MgSO}_{4}$, and evaporated under vacuum. The crude product was purified by flash-column chromatography (silica gel, cyclohexane/EtOAc as gradient from 100:0 to 95:5, v/v)) to provide the title compound ( $270 \mathrm{mg}, 0.70 \mathrm{mmol}, 32 \%$ yield) as a light yellow oil. This procedure was applied several times in order to get sufficient amount of product. The following ${ }^{1} \mathrm{H}$ NMR analysis was in accordance with literature data. ${ }^{14}{ }^{1} \mathrm{H}(300$ $\left.\mathrm{MHz}, \mathrm{CDCl}_{3}\right): \delta 4.73-4.64(\mathrm{~m}, 2 \mathrm{H}), 3.48(\mathrm{~d}, J=5.7 \mathrm{~Hz}, 2 \mathrm{H}), 2.54$ $-2.40(\mathrm{~m}, 1 \mathrm{H}), 2.26-2.14(\mathrm{~m}, 1 \mathrm{H}), 2.14-2.02(\mathrm{~m}, 1 \mathrm{H}), 2.02-$ $1.90(\mathrm{~m}, 2 \mathrm{H}), 1.67-1.54(\mathrm{~m}, 2 \mathrm{H}), 0.90(\mathrm{~s}, 9 \mathrm{H}), 0.05(\mathrm{~s}, 6 \mathrm{H})$.

Cyclohexadiene (4). To a solution of tert-butyl((3,4dibromocyclohexyl)methoxy)dimethylsilane 13 (685 mg, 1.77 mmol, 1 equiv.) in dry THF ( $25 \mathrm{~mL})$, at room temperature and under argon atmosphere, was added Aliquat $336(0.02 \mathrm{~mL}$, $0.035 \mathrm{mmol}, 0.02$ equiv.). $t$ BuOK (436 mg, $3.89 \mathrm{mmol}, 2.2$ equiv.) was rapidly added in one portion to the mixture, which was stirred for $3 \mathrm{~h}$. After, completion, the reaction was quenched with water $(5 \mathrm{~mL})$ and sat. aq. $\mathrm{NH}_{4} \mathrm{Cl}(20 \mathrm{~mL})$. The resulting mixture was extracted with EtOAc $(2 \times 30 \mathrm{~mL})$. Combined organic layer dried over $\mathrm{MgSO}_{4}$, and evaporated under vacuum. The crude product was partially purified by a rapid flash-column chromatography (silica gel, cyclohexane) and a light yellow oil was obtained, which was directly engaged in the next step. To a solution of tert-butyl(cyclohexa2,4-dien-1-ylmethoxy)dimethylsilane ( $\approx 1.77 \mathrm{mmol}, 1$ equiv.) in dry methanol $(10 \mathrm{~mL})$, at $0{ }^{\circ} \mathrm{C}$ and under argon atmosphere, was added acetyl chloride $(0.02 \mathrm{~mL}, 0.27 \mathrm{mmol}, 0.15$ equiv.) After $30 \mathrm{~min}$, the solvent was evaporated under vacuum. The crude product was partially purified by a rapid flash-column chromatography (silica gel, cyclohexane/EtOAc, 8:2, v/v) and a light yellow oil was obtained, which was in part directly engaged in the next step. To a solution of cyclohexa-2,4-dien1-ylmethanol (255 mg, $2.32 \mathrm{mmol}, 1.0$ equiv.) in dry MeCN (8 $\mathrm{mL}$ ) under argon atmosphere and room temperature, was added di(1H-imidazol-1-yl)methanone ( $451 \mathrm{mg}, 2.78 \mathrm{mmol}, 1.2$ equiv.). The reaction was stirred for $1 \mathrm{~h}$ at room temperature. After that time, 6-aminohexan-1-ol (326 mg, $2.78 \mathrm{mmol}, 1.2$ equiv.) was added and the reaction was stirred overnight. After completion, the solvent was removed by vacuum. The crude mixture was dissolved in DCM $(20 \mathrm{~mL})$ and was washed with $\mathrm{H}_{2} \mathrm{O}(2 \times 20 \mathrm{~mL})$, then brine $(20 \mathrm{~mL})$. The organic layer was dried over $\mathrm{MgSO}_{4}$ and solvents were removed by vacuum. The crude product was purified by flash-column chromatography (silica gel, cyclohexane/EtOAc as gradient from 100:0 to 60:40, $\mathrm{v} / \mathrm{v}$ ) to provide the racemic product $4(56 \mathrm{mg}, 0.22 \mathrm{mmol}, 49 \%$ yield) as a white solid. NB: Aromatized analog was observed by ${ }^{1} \mathrm{H}$ NMR (6\%) but was inseparable from the title compound by flash-column chromatography, RP-HPLC (Systems A and B) or recrystallization in water. The following ${ }^{1} \mathrm{H} N \mathrm{NMR}$ analysis was in accordance with literature data. ${ }^{14}{ }^{1} \mathrm{H}$ NMR $(300 \mathrm{MHz}$, acetone$\mathrm{d} 6)$ : $\delta 6.19(\mathrm{bs}, 1 \mathrm{H}), 6.00-5.60(\mathrm{~m}, 4 \mathrm{H}), 4.01-3.85(\mathrm{~m}, 2 \mathrm{H})$, $3.58-3.47(\mathrm{~m}, 2 \mathrm{H}), 3.11(\mathrm{dd}, J=13.0,6.9 \mathrm{~Hz}, 2 \mathrm{H}), 2.68-2.48$ (m, 1H), $2.30-2.16(m, 2 H), 1.60-1.25(m, 8 H)$. HPLC System $\mathrm{A}(\lambda=254 \mathrm{~nm}) t_{\mathrm{R}}=3.65 \mathrm{~min}$.

\section{Synthesis of oxazoles}

Oxazole (9). To a solution of (S)-ethyl 2-acetamido-3phenylpropanoate $(1.00 \mathrm{~g}, 4.25 \mathrm{mmol}, 1$ equiv.) in dry toluene (10 mL), was added $\mathrm{POCl}_{3}(0.61 \mathrm{~mL}, 6.38 \mathrm{mmol}, 1.5$ equiv.). The mixture was heated at $80^{\circ} \mathrm{C}$ for $3 \mathrm{~h}$. After completion, the reaction mixture was cooled to room temperature and poured onto a saturated solution of aq. $\mathrm{NaHCO}_{3}(100 \mathrm{~mL})$ cooled to 0 ${ }^{\circ} \mathrm{C}$. The aqueous layer was extracted with EtOAc $(2 \times 100 \mathrm{~mL})$. The organic layers were combined and washed with brine (50 $\mathrm{mL}$ ), dried over $\mathrm{MgSO}_{4}$, and evaporated under vacuum. The crude product was purified by flash-column chromatography (silica gel, cyclohexane/EtOAc 70:30, v/v) to furnish the corresponding product 8 (691 $\mathrm{mg}, 3.18 \mathrm{mmol}, 75 \%$ yield) as a yellow oil. The following ${ }^{1} \mathrm{H}$ NMR analysis was in accordance with literature data. ${ }^{27}{ }^{1} \mathrm{H} \mathrm{NMR}\left(300 \mathrm{MHz}, \mathrm{CDCl}_{3}\right): \delta 7.32-7.13$ $(\mathrm{m}, 5 \mathrm{H}), 4.07$ (q, $J=7.1 \mathrm{~Hz}, 2 \mathrm{H}), 3.71(\mathrm{~s}, 2 \mathrm{H}), 2.30(\mathrm{~s}, 3 \mathrm{H}), 1.31$ (t, $J=7.1 \mathrm{~Hz}, 3 \mathrm{H})$.

Tyrosine ethyl ester (14). To a solution of ethyl acetyl-Ltyrosinate $(1.454 \mathrm{~g}, 6.2 \mathrm{mmol}, 1$ equiv.) in dry DMF $(7.2 \mathrm{~mL})$, was added $\mathrm{K}_{2} \mathrm{CO}_{3}(1.5 \mathrm{~g}, 12.4 \mathrm{mmol}, 2$ equiv.). The resulting reaction mixture was stirred at room temperature for $30 \mathrm{~min}$, then methyl iodide ( $1.17 \mathrm{~mL}, 12.4 \mathrm{mmol}, 2$ equiv.) was added. The reaction mixture was stirred at room temperature for 12 h. The solution was diluted with EtOAc $(30 \mathrm{~mL})$ and the resulting solution was washed with water $(5 \times 50 \mathrm{~mL})$, dried over $\mathrm{MgSO}_{4}$, and evaporated under vacuum. The crude product was purified by flash-column chromatography (silica gel, cyclohexane/EtOAc 50:50, v/v) to provide the title compound (1.095 g, $3.39 \mathrm{mmol}, 61 \%$ yield) as a white amorphous powder. $\mathrm{mp} 56{ }^{\circ} \mathrm{C}$. IR (neat): 3312, 1736, 1635, $1514,1374,1294,1225,1198,1138,1077,1006,862 .{ }^{1} \mathrm{H}(300$ $\left.\mathrm{MHz}, \mathrm{CDCl}_{3}\right): \delta 7.02(\mathrm{~d}, J=8.7 \mathrm{~Hz}, 2 \mathrm{H}), 6.82(\mathrm{~d}, J=8.7 \mathrm{~Hz}, 2 \mathrm{H})$, $5.94(\mathrm{~d}, J=7.5 \mathrm{~Hz}, 1 \mathrm{H}), 4.81(\mathrm{dt}, J=7.8,5.8 \mathrm{~Hz}, 1 \mathrm{H}), 4.60(\mathrm{~s}$, $2 \mathrm{H}), 4.16(\mathrm{tt}, J=7.2,3.7 \mathrm{~Hz}, 2 \mathrm{H}), 3.80(\mathrm{~s}, 3 \mathrm{H}), 3.06(\mathrm{dd}, J=5.7$, $1.8 \mathrm{~Hz}, 2 \mathrm{H}), 1.98(\mathrm{~s}, 3 \mathrm{H}), 1.24(\mathrm{t}, J=7.2 \mathrm{~Hz}, 2 \mathrm{H}) .{ }^{13} \mathrm{C}$ NMR $(75$ $\left.\mathrm{MHz}, \mathrm{CDCl}_{3}\right): \delta 171.68,169.73,169.27,156.78,130.32,129.23$, $114.54,65.19,61.29,53.24,52.09,36.90,22.86,14.00$. HRMS $(\mathrm{ESI}+)$ Calculated for $\mathrm{C}_{16} \mathrm{H}_{22} \mathrm{NO}_{6}[\mathrm{M}+\mathrm{H}]^{+}: 324.1447$; found : 324.1459.

Oxazole Methyl ester (15). To a solution of ethyl (S)-2acetamido-3-(4-(2-methoxy-2-oxoethoxy)phenyl)propanoate $13(500 \mathrm{~g}, 1.54 \mathrm{mmol}, 1$ equiv.) in dry toluene $(5 \mathrm{~mL})$, was added $\mathrm{POCl}_{3}(187 \mathrm{~mL}, 2.01 \mathrm{mmol}, 1.3$ equiv.). The resulting reaction mixture was stirred at $80{ }^{\circ} \mathrm{C}$ for $4.5 \mathrm{~h}$. After completion, the solution was added dropwise to a solution of saturated aq. $\mathrm{NaHCO}_{3}(50 \mathrm{~mL})$, and the resulting mixture was extracted with EtOAc $(3 \times 25 \mathrm{~mL})$. The organic layers were combined, dried over MgSO4, and evaporated under vacuum. The crude product was purified by flash-column chromatography (silica gel, cyclohexane/EtOAc 50:50, v/v) to furnish the title comound ( $454.2 \mathrm{mg}, 1.49 \mathrm{mmol}, 97 \%$ yield) as a pale yellow oil. IR (neat): 2993, 2955, 1760, 1669, 1612, $1586,1510,1438,1375,1348,1269,1204,1176,1085,1022$, 
953, 909. ${ }^{1} \mathrm{H}\left(300 \mathrm{MHz}, \mathrm{CDCl}_{3}\right): \delta 7.17(\mathrm{~d}, J=8.3 \mathrm{~Hz}, 2 \mathrm{H}), 6.87-$ $6.78(\mathrm{~d}, J=8.3 \mathrm{~Hz}, 2 \mathrm{H}), 4.59(\mathrm{~d}, J=0.9 \mathrm{~Hz}, 2 \mathrm{H}), 4.07$ (qd, $J=7.1$, $1.2 \mathrm{~Hz}, 2 \mathrm{H}), 3.79(\mathrm{~d}, J=1.4 \mathrm{~Hz}, 3 \mathrm{H}), 3.63(\mathrm{~s}, 2 \mathrm{H}), 2.29(\mathrm{~d}, J=1.1$ $\mathrm{Hz}, 3 \mathrm{H}), 1.31(\mathrm{td}, J=7.1,1.2 \mathrm{~Hz}, 3 \mathrm{H}) .{ }^{13} \mathrm{C} \mathrm{NMR}\left(75 \mathrm{MHz}, \mathrm{CDCl}_{3}\right)$ : $\delta 169.61,156.38,153.98,152.55,132.97,129.71,115.96$, $114.74,70.47,65.59,52.28,30.16,15.11,14.40$. HRMS (ESI+) Calculated for $\mathrm{C}_{16} \mathrm{H}_{20} \mathrm{NO}_{5}[\mathrm{M}+\mathrm{H}]^{+}$: 306.1341 ; found :306.1341.

Oxazole (10). To a solution of methyl 2-(4-((5-ethoxy-2methyloxazol-4-yl)methyl)phenoxy)acetate 14 (200 mg, 0.644 mmol, 1 equiv.) in THF $(6 \mathrm{~mL})$, were successively added deionized water $(0.91 \mathrm{~mL})$ and $\mathrm{LiOH}(31 \mathrm{mg}, 1.31 \mathrm{mmol}, 2$ equiv.). The resulting reaction mixture was stirred at $70{ }^{\circ} \mathrm{C}$ for $3 \mathrm{~h}$. After completion, the reaction mixture was cooled to room temperature and glacial AcOH was added $(150 \mathrm{~mL}, 2.62$ mmol, 4 equiv.). The reaction mixture was stirred at room temperature for $1 \mathrm{~h}$. The solution was diluted with deionized water $(2 \mathrm{~mL})$ and extracted with EtOAc $(3 \times 20 \mathrm{~mL})$, and the combined organic layers dried over $\mathrm{MgSO}_{4}$, and evaporated under vacuum. The crude product was co-evaporated several times with toluene $(5 \times 8 \mathrm{~mL})$ to obtained the title compound (137 mg, $0.47 \mathrm{mmol}, 72 \%$ yield) as a colorless oil. IR (neat): 2927, 2507, 1739, 1673, 1612, 1583, 1510, 1440, 1375, 1250, $1207,1177,1112,1078,1013,976,909 .{ }^{1} \mathrm{H}\left(300 \mathrm{MHz}, \mathrm{CDCl}_{3}\right): \delta$ $11.43(\mathrm{~s}, 1 \mathrm{H}), 7.13(\mathrm{~d}, J=8.7 \mathrm{~Hz}, 2 \mathrm{H}), 6.85-6.73(\mathrm{~d}, J=8.7 \mathrm{~Hz}$, $2 \mathrm{H}), 4.53(\mathrm{~s}, 2 \mathrm{H}), 4.09(\mathrm{q}, J=7.1 \mathrm{~Hz}, 2 \mathrm{H}), 3.65(\mathrm{~s}, 2 \mathrm{H}), 2.33(\mathrm{~s}$, $3 \mathrm{H}), 1.31(\mathrm{t}, J=7.1 \mathrm{~Hz}, 3 \mathrm{H}) .{ }^{13} \mathrm{C} \mathrm{NMR}\left(75 \mathrm{MHz}, \mathrm{CDCl}_{3}\right): \delta 171.94$, $156.59,153.94,153.64,132.15,129.69,115.42,114.69,70.76$, 65.47, 29.32, 15.06, 13.85. HRMS (ESI+) Calculated for $\mathrm{C}_{15} \mathrm{H}_{16} \mathrm{NO}_{5}[\mathrm{M}+\mathrm{H}]^{+}: 290.1028$; found : 290.1033 .

\section{Maleimide synthesis}

Maleimide-dansylamide (16). To a solution of 1-(2-aminoethyl)-pyrrole-2,5-dione hydrochloride $(113 \mathrm{mg}, 0.81 \mathrm{mmol}$, 2.2 equiv.) and dansyl chloride (100 $\mathrm{mg}, 0.37 \mathrm{mmol}, 1.0$ equiv.) in DMF ( $6 \mathrm{~mL}$ ) was added DIEA ( $142 \mu \mathrm{L}, 0.82 \mathrm{mmol}, 2.2$ equiv.). The reaction mixture was stirred at room temperature for $2 \mathrm{~h}$. After completion, the reaction was poured onto water $(60 \mathrm{~mL})$ and the aqueous layer was extracted with DCM $(3 \times 20 \mathrm{~mL})$. Combined organic layers were dried over $\mathrm{MgSO}_{4}$ and solvents were removed by vacuum. The crude product was purified by flash-column chromatography (silica gel, DCM/EtOAc 90:10, $\mathrm{v} / \mathrm{v}$ ) to provide the title compound ( $97 \mathrm{mg}, 0.26 \mathrm{mmol}, 70 \%$ yield) as a pale yellow solid. The following ${ }^{1} \mathrm{H}$ NMR analysis was in accordance with literature data. ${ }^{71} \mathrm{H}$ NMR $\left(300 \mathrm{MHz}, \mathrm{CDCl}_{3}\right)$ : $\delta 8.51(\mathrm{~d}, J=8.6 \mathrm{~Hz}, 1 \mathrm{H}), 8.24-8.15(\mathrm{~m}, 2 \mathrm{H}), 7.53$ (ddd, $J=$ 10.1, 8.6, 7.5 Hz, 2H), 7.17 (dd, $J=7.6,0.6 \mathrm{~Hz}, 1 \mathrm{H}), 6.34(\mathrm{~s}, 2 \mathrm{H})$, $5.07(\mathrm{t}, J=6.1 \mathrm{~Hz}, 1 \mathrm{H}), 3.53(\mathrm{t}, J=5.7 \mathrm{~Hz}, 2 \mathrm{H}), 3.16(\mathrm{dd}, J=$ $11.5,6.0 \mathrm{~Hz}, 2 \mathrm{H}), 2.88(\mathrm{~s}, 6 \mathrm{H})$. HPLC System A $(\lambda=254 \mathrm{~nm}) t_{\mathrm{R}}=$ $3.40 \mathrm{~min}$.

Chiral maleimide (19). To a solution of (R)-1-phenylethanol ( $500 \mathrm{mg}, 4.09 \mathrm{mmol}, 1.0$ equiv.) in dry THF $(15 \mathrm{~mL}, 0.41 \mathrm{M})$ and under argon atmosphere, cooled to $0{ }^{\circ} \mathrm{C}$, were successively added $\mathrm{PPh}_{3}(1.180 \mathrm{mg}, 4.5 \mathrm{mmol}, 1.1$ equiv.) and diisopropyl azodicarboxylate $(0.88 \mathrm{~mL}, 4.5 \mathrm{mmol}, 1.2$ equiv.). The reaction was stirred for $15 \mathrm{~min}$ at $0{ }^{\circ} \mathrm{C}$, then $1 \mathrm{H}$-pyrrole-2,5-dione $(597$ $\mathrm{mg}, 6.14 \mathrm{mmol}, 1.5$ equiv.) was introduced into the mixture, which was stirred for $30 \mathrm{~min}$ at $0{ }^{\circ} \mathrm{C}$, and overnight at room temperature. After completion, the solvent was removed by vacuum. The crude product was purified by flash-column chromatography (silica gel, cyclohexane/EtOAc 90:10, v/v). to furnish the title compound ( $278 \mathrm{mg}, 1.38 \mathrm{mmol}, 34 \%$ yield) as a yellow oil. The following ${ }^{1} \mathrm{H}$ NMR analysis was in accordance with literature data. ${ }^{55} \mathrm{H}$ NMR $\left(300 \mathrm{MHz}, \mathrm{CDCl}_{3}\right): \delta 7.43-7.37$ $(\mathrm{m}, 2 \mathrm{H}), 7.34-7.21(\mathrm{~m}, 3 \mathrm{H}), 6.61(\mathrm{~s}, 2 \mathrm{H}), 5.34(\mathrm{q}, J=7.4 \mathrm{~Hz}$, $1 \mathrm{H}), 1.81(\mathrm{~d}, J=7.4 \mathrm{~Hz}, 3 \mathrm{H})$. HPLC System A $(\lambda=254 \mathrm{~nm}) t_{\mathrm{R}}=$ $3.76 \mathrm{~min}$.

\section{Preparation of cycloadducts}

Cycloadduct linear diene-dansylamide (17a). To a solution of (2E,4E)-hexa-2,4-dien-1-ol 1 (10.6 mg, $0.108 \mathrm{mmol}, 2.0$ equiv.) in a solution of THF/ $\mathrm{H}_{2} \mathrm{O}(0.5 \mathrm{~mL}, 2: 1 \mathrm{v} / \mathrm{v})$ was added a solution of 16 (20 $\mathrm{mg}, 0.054 \mathrm{mmol}, 1.0$ equiv.) in $\mathrm{THF} / \mathrm{H}_{2} \mathrm{O}(0.5 \mathrm{~mL}, 2: 1 \mathrm{v} / \mathrm{v})$. The mixture was stirred at room temperature for 2 days. After completion, the reaction mixture was diluted with water $(10 \mathrm{~mL})$ and the aqueous layer extracted with EtOAc $(3 \times 10 \mathrm{~mL})$. The organic layers were combined, dried over $\mathrm{MgSO}_{4}$, and solvents were removed under vacuum. The crude product was purified by flash-column chromatography (silica gel, DCM/EtOAc as gradient from $100: 0$ to $90: 10,80: 20$ and $50: 50 \mathrm{v} / \mathrm{v}$ ) to provide the title compound ( $22 \mathrm{mg}, 0.047 \mathrm{mmol}, 86 \%$ yield) as a pale yellow oil. IR (neat): 3451, 3284, 2926, 2851, 1767, 1684, 1588, 1573, 1403, 1327, 1141, 975, 945, 789.

${ }^{1} \mathrm{H}$ NMR (300 MHz, MeOD): $\delta 8.56(\mathrm{~d}, J=8.5 \mathrm{~Hz}, 1 \mathrm{H}), 8.26(\mathrm{~d}, J=8.7$ $\mathrm{Hz}, 1 \mathrm{H}), 8.14$ (dd, $J=7.3,1.2 \mathrm{~Hz}, 1 \mathrm{H}), 7.63-7.52(\mathrm{~m}, 2 \mathrm{H}), 7.29$ (d, $J=$ $7.6 \mathrm{~Hz}, 1 \mathrm{H}), 5.69(\mathrm{dt}, J=9.0,3.0 \mathrm{~Hz}, 1 \mathrm{H}), 5.61(\mathrm{dt}, J=9.2,2.9 \mathrm{~Hz}$, $1 \mathrm{H}), 3.97(\mathrm{dd}, J=11.1,6.9 \mathrm{~Hz}, 1 \mathrm{H}), 3.86(\mathrm{dd}, J=11.0,8.1 \mathrm{~Hz}, 1 \mathrm{H})$, $3.39(\mathrm{t}, J=6.1 \mathrm{~Hz}, 2 \mathrm{H}), 2.97(\mathrm{t}, J=6.2 \mathrm{~Hz}, 2 \mathrm{H}), 2.95-2.90(\mathrm{~m}, 1 \mathrm{H})$, $2.88(\mathrm{~s}, 6 \mathrm{H}), 2.73(\mathrm{dd}, J=8.4,7.0 \mathrm{~Hz}, 1 \mathrm{H}), 2.41-2.30(\mathrm{~m}, 2 \mathrm{H}), 1.34(\mathrm{~d}$, $J=7.4 \mathrm{~Hz}, 3 \mathrm{H}), 1.31-1.24(\mathrm{~m}, 1 \mathrm{H}) .{ }^{13} \mathrm{C}$ NMR $(75 \mathrm{MHz}, \mathrm{MeOD}): \delta$ $179.6,179.2,153.2,136.8,135.8,131.2,130.8,130.3,129.2,124.4$, $120.6,116.5,63.4,46.2,45.8,43.8,40.8,40.1,38.9,32.2,17.1$. HRMS (ESI+) Calculated for $\mathrm{C}_{24} \mathrm{H}_{30} \mathrm{~N}_{3} \mathrm{O}_{5} \mathrm{~S}[\mathrm{M}+\mathrm{H}]^{+}$: 472.1906 ; found : 472.1895. HPLC System $B(\lambda=330 \mathrm{~nm}) t_{R}=3.84 \mathrm{~min}$.

Cycloadduct cyclopentadiene-dansylamide (17b). To a solution of 1-(2-(2-(2-azidoethoxy)ethoxy)ethyl)cyclopenta1,3-diene and 2-(2-(2-(2-azidoethoxy)ethoxy)ethyl)cyclopenta1,3-diene 2 (47 mg, $0.21 \mathrm{mmol}, 5.0$ equiv.) in a solution of $\mathrm{MeCN} / \mathrm{H}_{2} \mathrm{O}(1 \mathrm{~mL}, 1: 2 \mathrm{v} / \mathrm{v})$ was added compound $16(15 \mathrm{mg}$, $0.042 \mathrm{mmol}, 1.0$ equiv.). The mixture was stirred at room temperature for $3 \mathrm{~h}$. After completion, the reaction mixture was diluted with water $(10 \mathrm{~mL})$ and the aqueous layer extracted with EtOAc $(2 \times 10 \mathrm{~mL})$. Combined organic layers were dried over $\mathrm{MgSO}_{4}$, and solvents were removed under vaccum. The crude product was purified by flash-column chromatography (silica gel, DCM/EtOAc as gradient from 100:0 to $90: 10$, and $80: 20, \mathrm{v} / \mathrm{v}$ ) to obtain the product $(22 \mathrm{mg}, 0.037$ mmol, $92 \%$ yield) as a dark yellow foam. At least 2 stereoisomers were observed by NMR in a ratio of 0.83:1.00. IR (neat): 3276, 2925, 2868, 2100, 1769, 1692, 1588, 1574, $1396,1329,1143,909,790,727 .{ }^{1} \mathrm{H}$ NMR $\left(300 \mathrm{MHz}, \mathrm{CDCl}_{3}\right): \delta$ $8.52(\mathrm{~d}, J=8.6 \mathrm{~Hz}, 2 \mathrm{H}$ ), $8.25(\mathrm{~d}, J=8.7 \mathrm{~Hz}, 2 \mathrm{H}), 8.20$ (ddd, $J=$ 7.3, 3.4, 1.2 Hz, 2H), 7.59 (dd, $J=8.5,7.7 \mathrm{~Hz}, 1.9 \mathrm{H}$ ), $7.55-7.46$ $(\mathrm{m}, 2.1 \mathrm{H}), 7.17(\mathrm{~d}, J=7.6 \mathrm{~Hz}, 2 \mathrm{H}), 5.93(\mathrm{dd}, J=5.7,3.0 \mathrm{~Hz}$, 
$0.8 \mathrm{H}), 5.80(\mathrm{~d}, J=5.6 \mathrm{~Hz}, 0.8 \mathrm{H}), 5.64-5.50(\mathrm{~m}, 1 \mathrm{H}), 5.38-5.30$ $(\mathrm{t}, J=5.6 \mathrm{~Hz}, 1 \mathrm{H}), 5.11(\mathrm{~d}, J=5.6 \mathrm{~Hz}, 0.9 \mathrm{H}), 3.70-3.57(\mathrm{~m}$, $11 \mathrm{H}), 3.57-3.42(\mathrm{~m}, 8 \mathrm{H}), 3.41-3.33(\mathrm{~m}, 8 \mathrm{H}), 3.25-3.18(\mathrm{~m}$, $2 \mathrm{H}), 3.16-3.11(\mathrm{~m}, 1 \mathrm{H}), 3.09-2.96(\mathrm{~m}, 5 \mathrm{H}), 2.94(\mathrm{dd}, J=2.8$, $1.5 \mathrm{~Hz}, 2 \mathrm{H}), 2.87(\mathrm{~s}, 11 \mathrm{H}), 2.36-2.02(\mathrm{~m}, 6 \mathrm{H}), 1.74-1.64(\mathrm{~m}$, 2.7H), $1.41(\mathrm{t}, J=9.4 \mathrm{~Hz}, 3 \mathrm{H}), 1.29-1.24(\mathrm{~m}, 1.8 \mathrm{H}), 1.21(\mathrm{t}, J=$ $7.0 \mathrm{~Hz}, 1.8 \mathrm{H}), 1.14(\mathrm{~d}, J=6.4 \mathrm{~Hz}, 1 \mathrm{H}), 0.92-0.77(\mathrm{~m}, 2.9 \mathrm{H}) .{ }^{13} \mathrm{C}$ NMR $\left(75 \mathrm{MHz}, \mathrm{CDCl}_{3}\right): \delta 178.3,177.8,177.7,177.4,152.0$, $152.0,146.9,137.8,134.5,134.4,134.2,130.4,130.4,129.9$, $129.9,129.8,129.4,129.4,128.4,128.4,126.3,123.3,119.0$, $118.9,115.2,70.7,70.5,70.1,70.0,70.0,69.9,69.0,68.7,56.7$, 55.7, 52.1, 50.7, 50.7, 48.9, 48.1, 47.3, 46.9, 45.7, 45.4, 45.2, $44.7,41.9,41.7,37.5,37.2,31.1,30.6,29.7$. HRMS (ESI+) Calculated for $\mathrm{C}_{29} \mathrm{H}_{36} \mathrm{~N}_{6} \mathrm{O}_{6} \mathrm{~S}[\mathrm{M}+\mathrm{H}]^{+}$: 597.2495 ; found : 597.2493. HPLC System A $(\lambda=254 \mathrm{~nm}) t_{\mathrm{R}}=4.56 \mathrm{~min}, 4.61 \mathrm{~min}$.

Cycloadduct fulvene-dansylamide (17c). To a solution of 5(cyclopenta-2,4-dien-1-ylidene)hexanoic acid $3(10 \mathrm{mg}, 0.058 \mathrm{mmol}$, 1.0 equiv.) in a solution of $\mathrm{THF} / \mathrm{H}_{2} \mathrm{O}(0.7 \mathrm{~mL}, 2: 1 \mathrm{v} / \mathrm{v})$ was added a solution of 16 (24 mg, $0.064 \mathrm{mmol}, 1.1$ equiv.) in $\mathrm{THF} / \mathrm{H}_{2} \mathrm{O}(0.5 \mathrm{~mL}$, $2: 1 \mathrm{v} / \mathrm{v}$ ). The mixture was stirred at room temperature for $3 \mathrm{~h}$. After completion, the reaction mixture was diluted with water $(10 \mathrm{~mL})$ and the aqueous layer extracted with EtOAc $(3 \times 10 \mathrm{~mL})$. The organic layers were combined, dried over $\mathrm{MgSO}_{4}$, and solvents were removed under vacuum. The crude product was purified by flash-column chromatography (silica gel, DCM/EtOAc/MeOH as gradient from 100:0:0 to 90:10:0, 80:20:0, 70:30:0 and 50:40:10 $\mathrm{v} / \mathrm{v}$ ) to provide the title compound ( $29 \mathrm{mg}, 0.053 \mathrm{mmol}, 91 \%$ yield) as a pale yellow oil. IR (neat):3268, 2927, 2858, 2794, 2253, 1770, $1689,1589,1575,1397,1324,1143,909,728 .{ }^{1} \mathrm{H}$ NMR $(300 \mathrm{MHz}$, $\left.\mathrm{CDCl}_{3}\right): \delta 8.52(\mathrm{~d}, J=8.5 \mathrm{~Hz}, 1 \mathrm{H}), 8.30-8.13(\mathrm{~m}, 2 \mathrm{H}), 7.65-7.45(\mathrm{~m}$, $2 \mathrm{H}), 7.19$ (d, J = 7.5 Hz, 1H), $6.12-6.01(\mathrm{~m}, 2 \mathrm{H}), 5.22$ (bs, 1H), $3.76-$ $3.63(\mathrm{~m}, 2 \mathrm{H}), 3.40$ (overlaped triplet, $J=5.7 \mathrm{~Hz}, 2 \mathrm{H}), 3.03(\mathrm{dd}, J=$ $11.4,5.8 \mathrm{~Hz}, 2 \mathrm{H}), 2.98-2.89(\mathrm{~m}, 1 \mathrm{H}), 2.85(\mathrm{~s}, 6 \mathrm{H}$, overlaped with multiplet at $2.84 \mathrm{ppm}), 2.84(\mathrm{~m}, 1 \mathrm{H}$, overlaped with singlet at 2.85 ppm), 2.29 (overlaped triplet, $J=7.2 \mathrm{~Hz}, 2 \mathrm{H}$ ), $1.97(\mathrm{t}, J=7.3 \mathrm{~Hz}, 2 \mathrm{H}$ ) $1.70(\mathrm{dt}, J=7.2,7.2 \mathrm{~Hz}, 2 \mathrm{H}), 1.54(\mathrm{~s}, 3 \mathrm{H}) .{ }^{13} \mathrm{C} \mathrm{NMR}\left(75 \mathrm{MHz}, \mathrm{CDCl}_{3}\right)$ : $\delta 178.4,177.4,177.3,151.9,148.7,134.8,134.7,134.4,130.4$, $129.8,129.4,128.5,123.3,119.0,118.96,115.3,113.9,45.4,45.1$, $44.8,44.4,44.2,41.6,37.5,32.9,32.6,22.6,16.9$. HRMS (ESI-) Calculated for $\mathrm{C}_{29} \mathrm{H}_{34} \mathrm{~N}_{3} \mathrm{O}_{6} \mathrm{~S}[\mathrm{M}+\mathrm{H}]^{+}: 552.2168$; found : 552.2166 . HPLC System $B(\lambda=330 \mathrm{~nm}) t_{\mathrm{R}}=4.16 \mathrm{~min}, 4.25 \mathrm{~min}$.

Cycloadduct furan-dansylamide (17d). To a solution of furan-2ylmethanol $6(25 \mathrm{mg}, 0.27 \mathrm{mmol}, 5.0$ equiv.) in a solution of $\mathrm{THF} / \mathrm{H}_{2} \mathrm{O}(1.0 \mathrm{~mL}, 2: 1 \mathrm{v} / \mathrm{v})$ was added a solution of $16(20 \mathrm{mg}, 0.054$ mmol, 1.0 equiv.) in $\mathrm{THF} / \mathrm{H}_{2} \mathrm{O}(0.5 \mathrm{~mL}, 2: 1 \mathrm{v} / \mathrm{v})$. The mixture was stirred at room temperature for 3 days. After completion, the reaction mixture was diluted with water $(10 \mathrm{~mL})$ and the aqueous layer extracted with EtOAc $(3 \times 15 \mathrm{~mL})$. The organic layers were combined, dried over $\mathrm{MgSO}_{4}$, and solvents were removed under vacuum. The crude product was purified by flash-column chromatography (silica gel, DCM/EtOAc as gradient from 100:0 to $90: 10,80: 20,70: 30,60: 40$ and $50: 50 \mathrm{v} / \mathrm{v}$ ) to provide the title compound ( $21 \mathrm{mg}, 0.045 \mathrm{mmol}, 82 \%$ yield) as a pale yellow oil. IR (neat): 3483, 3290, 2921, 2828, 1692, 1398, 1323, 1141, 789. ${ }^{1} \mathrm{H}$ NMR (300 MHz, MeOD): $\delta 8.61-8.51(\mathrm{~m}, 1.4 \mathrm{H}), 8.27(\mathrm{~d}, J=8.7 \mathrm{~Hz}$, $1 \mathrm{H}), 8.26(\mathrm{~d}, J=8.7 \mathrm{~Hz}, 0.35 \mathrm{H}), 8.15(\mathrm{dd}, J=7.4,1.0 \mathrm{~Hz}, 1.34 \mathrm{H}), 7.64$ $-7.51(\mathrm{~m}, 2.75 \mathrm{H}), 7.29(\mathrm{~d}, J=7.3 \mathrm{~Hz}, 1 \mathrm{H}), 7.27(\mathrm{~d}, J=7.7 \mathrm{~Hz}, 0.36 \mathrm{H})$, $6.52-6.46(\mathrm{~m}, 0.67 \mathrm{H}), 6.35(\mathrm{dd}, J=5.8,1.6 \mathrm{~Hz}, 1 \mathrm{H}), 6.22(\mathrm{~d}, J=5.8$ $\mathrm{Hz}, 1 \mathrm{H}), 5.14(\mathrm{dd}, J=5.5,1.6 \mathrm{~Hz}, 1 \mathrm{H}), 5.03(\mathrm{~d}, J=1.0 \mathrm{~Hz}, 0.34 \mathrm{H}), 4.86$ $(\mathrm{s}, 8 \mathrm{H}), 4.15-3.95(\mathrm{~m}, 2.48 \mathrm{H}), 3.80(\mathrm{~d}, J=12.8 \mathrm{~Hz}, 0.33 \mathrm{H}), 3.45(\mathrm{t}, J$
$=6.5 \mathrm{~Hz}, 0.84 \mathrm{H}), 3.35(\mathrm{~s}, 2.77 \mathrm{H}), 3.25(\mathrm{dd}, J=7.6,5.5 \mathrm{~Hz}, 1.35 \mathrm{H})$, $3.06(\mathrm{~d}, J=7.8 \mathrm{~Hz}, 1 \mathrm{H}), 3.05(\mathrm{~d}, J=6.1 \mathrm{~Hz}, 0.66 \mathrm{H}), 2.96(\mathrm{t}, J=6.1 \mathrm{~Hz}$ 2.25H), $2.88(\mathrm{~s}, 6 \mathrm{H}), 2.86(\mathrm{~s}, 2 \mathrm{H}), 2.60(\mathrm{~d}, J=6.4 \mathrm{~Hz}, 0.34 \mathrm{H}), 2.52(\mathrm{~d}, J$ $=6.5 \mathrm{~Hz}, 0.34 \mathrm{H}) .{ }^{13} \mathrm{C}$ NMR $(75 \mathrm{MHz}, \mathrm{MeOD}): \delta 178.0,176.9,176.8$, $176.6,153.3,138.8,138.0,136.7,136.6,136.2,131.3,131.26$, $130.8,130.77,130.4,130.35,129.2,124.4,120.6,116.6,93.5,92.9$, 82.1, 80.4, 61.5, 60.8, 51.5, 46.7, 45.8, 40.9, 40.7, 39.4, 38.9. HRMS $(\mathrm{ESI}+)$ Calculated for $\mathrm{C}_{23} \mathrm{H}_{26} \mathrm{~N}_{3} \mathrm{O}_{6} \mathrm{~S}[\mathrm{M}+\mathrm{H}]^{+}: 472.1542$; found: 472.1541. HPLC System $B(\lambda=330 \mathrm{~nm}) t_{\mathrm{R}}=3.19 \mathrm{~min}, 3.49 \mathrm{~min}$.

Azaphtalimide - coumarin (18). To a solution of 6-(5ethoxy-2-methyloxazol-4-yl)hexanoic acid $7(9.4 \mathrm{mg}, 0.039$ mmol, 1.0 equiv.) in a solution of $\mathrm{THF} / \mathrm{H}_{2} \mathrm{O}(0.5 \mathrm{~mL}, 2: 1 \mathrm{v} / \mathrm{v})$ were added 7-(diethylamino)- $\mathrm{N}$-(2-(2,5-dioxo-2,5-dihydro- $1 \mathrm{H}$ pyrrol-1-yl)ethyl)-2-oxo-2H-chromene-3-carboxamide MC $^{42}$ (15 $\mathrm{mg}, 0.039 \mathrm{mmol}, 1.0$ equiv.) and TFA ( $3 \mu \mathrm{L}, 0.043 \mathrm{mmol}, 1.1$ equiv.). The mixture was stirred at room temperature for $26 \mathrm{~h}$. After completion, and solvents were removed under vacuum. The crude product was purified by RP-HPLC (System D) and fractions were collected and lyophilized to provide the title compound (12 mg, $0.019 \mathrm{mmol}, 49 \%$ yield) as a yellow powder. IR (neat): 3330, 2976, 2927, 2858, 1708, 1617, 1581, $1514,1402,1352,1227,1189,1134,910,795 .{ }^{1} \mathrm{H}$ NMR $(300$ MHz, DMSO-d6): $\delta 11.95$ (bs, $1 \mathrm{H}), 8.74(\mathrm{t}, J=6.1 \mathrm{~Hz}, 1 \mathrm{H}), 8.57$ $(\mathrm{s}, 1 \mathrm{H}), 7.65(\mathrm{~d}, J=9.0 \mathrm{~Hz}, 1 \mathrm{H}), 6.79(\mathrm{dd}, J=8.9,2.3 \mathrm{~Hz}, 1 \mathrm{H})$, $6.60(\mathrm{~d}, J=2.0 \mathrm{~Hz}, 1 \mathrm{H}), 3.76-3.65(\mathrm{~m}, 2 \mathrm{H}), 3.58-3.50(\mathrm{~m}, 2 \mathrm{H})$, $3.48(\mathrm{q}, J=7.0 \mathrm{~Hz}, 4 \mathrm{H}), 2.81(\mathrm{t}, J=7.6 \mathrm{~Hz}, 2 \mathrm{H}), 2.58(\mathrm{~s}, 3 \mathrm{H}), 2.20$ $(\mathrm{t}, J=7.3 \mathrm{~Hz}, 3 \mathrm{H}), 1.69-1.57(\mathrm{~m}, 2 \mathrm{H}), 1.56-1.46(\mathrm{~m}, 2 \mathrm{H}), 1.42$ $-1.31(\mathrm{~m}, 2 \mathrm{H}), 1.14(\mathrm{t}, J=7.0 \mathrm{~Hz}, 6 \mathrm{H}) .{ }^{13} \mathrm{C} \mathrm{NMR}(75 \mathrm{MHz}$, DMSO-d6): $\delta$ 174.5, 168.0, 162.8, 161.3, 157.2, 152.4, 147.6, $131.5,120.4,110.1,109.4,107.6,95.9,44.3,37.6,37.4,33.6$, 32.1, 28.4, 27.3, 24.3, 19.6, 12.3. HRMS (ESI+) Calculated for $\mathrm{C}_{30} \mathrm{H}_{35} \mathrm{~N}_{4} \mathrm{O}_{8}[\mathrm{M}+\mathrm{H}]^{+}: 579.2455$; found : 579.2453. HPLC System $\mathrm{A}(\lambda=254 \mathrm{~nm}) t_{\mathrm{R}}=3.96 \mathrm{~min}$.

Cycloadduct linear diene-chiral maleimide (20). To a solution of (2E,4E)-hexa-2,4-dien-1-ol 1 ( $25 \mathrm{mg}, 0.25 \mathrm{mmol}, 1.0$ equiv.) in a solution of $\mathrm{THF} / \mathrm{H}_{2} \mathrm{O}(1 \mathrm{~mL}, 2: 1 \mathrm{v} / \mathrm{v})$ was added a solution of 19 (50 mg, $0.25 \mathrm{mmol}, 1.0$ equiv.) in THF/ $\mathrm{H}_{2} \mathrm{O}(1$ $\mathrm{mL}, 2: 1 \mathrm{v} / \mathrm{v})$. The mixture was stirred at room temperature for 3 days. After completion, the reaction mixture was diluted with water $(10 \mathrm{~mL})$ and the aqueous layer extracted with EtOAc $(3 \times 15 \mathrm{~mL})$. The organic layers were combined, dried over $\mathrm{MgSO}_{4}$, and solvents were removed under vacuum. The crude product was purified by flash-column chromatography (silica gel, cyclohexane/EtOAc as gradient from 100:0 to 90:10, $80: 20$ and $70: 30 \mathrm{v} / \mathrm{v}$ ) to provide the title compound $(59 \mathrm{mg}$, $0.20 \mathrm{mmol}, 79 \%$ yield) as a pale yellow oil. Two stereoisomers were observed by NMR in a ratio of 1:1. IR (neat): 3437, 3090, 3065, 3034, 2969, 2934, 2878, 2847, 1764, 1687, 1452, 1363, $1225,1189,912,727,694 .{ }^{1} \mathrm{H}$ NMR $\left(300 \mathrm{MHz} \mathrm{CDCl}_{3}\right): \delta 7.37-$ $7.19(\mathrm{~m}, 10 \mathrm{H}), 5.82-5.54(\mathrm{~m}, 4 \mathrm{H}), 5.35(\mathrm{q}, J=7.2 \mathrm{~Hz}, 1 \mathrm{H}), 5.35$ $(q, J=7.2 \mathrm{~Hz}, 1 \mathrm{H}), 4.05-3.85(\mathrm{~m}, 3 \mathrm{H}), 3.76(\mathrm{t}, J=10.5 \mathrm{~Hz}, 1 \mathrm{H})$, 3.28 (dd, $J=15.9,7.4 \mathrm{~Hz}, 1 \mathrm{H}$ ), 3.16 (bs, $1 \mathrm{H}$ ), 3.00 (ddd, $J=8.6$, $6.2,5.0 \mathrm{~Hz}, 2 \mathrm{H}), 2.62-2.49(\mathrm{~m}, 2 \mathrm{H}), 2.49-2.32(\mathrm{~m}, 2 \mathrm{H}), 1.72$ (d, $J=7.3 \mathrm{~Hz}, 3 \mathrm{H}), 1.71(\mathrm{~d}, J=7.3 \mathrm{~Hz}, 3 \mathrm{H}), 1.48(\mathrm{~d}, J=7.4 \mathrm{~Hz}$, $3 \mathrm{H}), 1.43(\mathrm{~d}, J=7.4 \mathrm{~Hz}, 3 \mathrm{H}) .{ }^{13} \mathrm{C} \mathrm{NMR}\left(75 \mathrm{MHz}, \mathrm{CDCl}_{3}\right): \delta 178.8$, $178.7,177.3,177.2,139.2,139.2,135.2,135.2,128.4,128.3$, 128.2, 128.2, 127.6, 127.5, 127.1, 127.1, 62.7, 62.7, 49.8, 44.7, $44.6,42.6,42.4$, 38.2, 31.2, 16.7, 16.7, 16.5, 16.4. HRMS (ESI+) 
Calculated for $\mathrm{C}_{18} \mathrm{H}_{22} \mathrm{NO}_{3}[\mathrm{M}+\mathrm{H}]^{+}: 300.1600$; found : 300.1609 . HPLC System $A(\lambda=254 \mathrm{~nm}) t_{\mathrm{R}}=3.88 \mathrm{~min}$.

Cycloadduct cyclopentadiene-chiral maleimide (21). To a solution of 1-(2-(2-(2-azidoethoxy)ethoxy)ethyl)cyclopenta1,3-diene and 2-(2-(2-(2-azidoethoxy)ethoxy)ethyl)cyclopenta1,3-diene 2 (39 mg, $0.17 \mathrm{mmol}, 1.0$ equiv.) in a solution of $\mathrm{THF} / \mathrm{H}_{2} \mathrm{O}(1 \mathrm{~mL}, 2: 1 \mathrm{v} / \mathrm{v})$ was added a solution of $19(50 \mathrm{mg}$, $0.25 \mathrm{mmol}, 1.0$ equiv.) in $\mathrm{THF} / \mathrm{H}_{2} \mathrm{O}(1 \mathrm{~mL}, 2: 1 \mathrm{v} / \mathrm{v})$. The mixture was stirred at room temperature for $2 \mathrm{~h}$. After completion, the reaction mixture was diluted with water $(10 \mathrm{~mL})$ and the aqueous layer extracted with EtOAc $(2 \times 15 \mathrm{~mL})$. Combined organic layers were dried over $\mathrm{MgSO}_{4}$, and solvents were removed under vacuum. The crude product was purified by flash-column chromatography (silica gel, cyclohexane/EtOAc as gradient from 100:0 to $90: 10,80: 20$ and $70: 30, \mathrm{v} / \mathrm{v}$ ) to provide the title compound ( $65 \mathrm{mg}, 0.15 \mathrm{mmol}, 90 \%$ yield) as a white foam. At least 4 stereoisomers were observed by NMR in a ratio 1.00:1.00:1.70:0.95. IR (neat): 2941, 2968, 2100, 1694, 1453, 1354, 1188, 1113, 913, 728, 698. ${ }^{1} \mathrm{H}$ NMR $(300 \mathrm{MHz}$, $\left.\mathrm{CDCl}_{3}\right): \delta 7.43-7.34(\mathrm{~m}, 10 \mathrm{H}), 7.33-7.26(\mathrm{~m}, 9 \mathrm{H}), 7.25-7.18$ $(\mathrm{m}, 6 \mathrm{H}), 5.98(\mathrm{dd}, J=5.6,2.9 \mathrm{~Hz}, 1 \mathrm{H}), 5.89-5.81(\mathrm{~m}, 2 \mathrm{H}), 5.70$ (d, $J=5.0 \mathrm{~Hz}, 1 \mathrm{H}), 5.60-5.55(\mathrm{~m}, 1.7 \mathrm{H}), 5.50(\mathrm{~s}, 1 \mathrm{H}), 5.23(\mathrm{dd}, J$ $=14.5,7.6 \mathrm{~Hz}, 4.4 \mathrm{H}), 3.69-3.56(\mathrm{~m}, 29.5 \mathrm{H}), 3.56-3.47(\mathrm{~m}$, $7.4 \mathrm{H}), 3.41-3.33(\mathrm{~m}, 11.4 \mathrm{H}), 3.31-3.16(\mathrm{~m}, 18.9 \mathrm{H}), 3.01(\mathrm{dd}$, $J=7.3,6.1 \mathrm{~Hz}, 2.2 \mathrm{H}), 2.42-2.26(\mathrm{~m}, 2.5 \mathrm{H}), 2.26-2.10(\mathrm{~m}$, 4.3H), $1.97-1.83(\mathrm{~m}, 3.8 \mathrm{H}), 1.72-1.64(\mathrm{~m}, 20.5 \mathrm{H}), 1.49-1.42$ $(\mathrm{m}, 5.2 \mathrm{H}) .{ }^{13} \mathrm{C}$ NMR $\left(75 \mathrm{MHz}, \mathrm{CDCl}_{3}\right): \delta 177.8,177.7,177.4$, $177.4,177.2$, 177.2, 177.1, 177.1, 146.8, 146.7, 139.9, 139.6, $139.5,137.8,137.7,134.1,134.0,128.2,128.1,128.0,127.8$, 127.6, 127.6, 127.5, 127.5, 126.5, 126.5, 70.6, 70.6, 70.0, 69.9, $69.9,69.9,69.0,68.9,68.7,57.0,56.9,55.5,55.5,52.2,50.6$, $50.1,49.6,49.6,49.5,48.3,47.9,47.8,46.9,46.8,46.6,46.6$, $45.5,45.3,45.3,45.0,45.0,31.1,31.1,30.8,30.4,16.8,16.3$, 16.2, 16.0. HRMS (ESI+) Calculated for $\mathrm{C}_{23} \mathrm{H}_{29} \mathrm{~N}_{4} \mathrm{O}_{4}[\mathrm{M}+\mathrm{H}]^{+}$: 425.2189 ; found : 425.2180. HPLC System A $(\lambda=254 \mathrm{~nm}) t_{\mathrm{R}}=$ $4.55 \mathrm{~min}, 4.71 \mathrm{~min}$.

Cycloadduct fulvene-chiral maleimide (22). To a solution of 5-(cyclopenta-2,4-dien-1-ylidene)hexanoic acid $3(45 \mathrm{mg}$, $0.25 \mathrm{mmol}, 1.0$ equiv.) in a solution of $\mathrm{THF} / \mathrm{H}_{2} \mathrm{O}(0.75 \mathrm{~mL}, 2: 1$ $\mathrm{v} / \mathrm{v}$ ) was added a solution of 19 (30 $\mathrm{mg}, 0.15 \mathrm{mmol}, 1.0$ equiv.) in $\mathrm{THF} / \mathrm{H}_{2} \mathrm{O}(0.5 \mathrm{~mL}, 2: 1 \mathrm{v} / \mathrm{v})$. The mixture was stirred at room temperature for 3 days. After completion, the reaction mixture was diluted with water $(10 \mathrm{~mL})$ and the aqueous layer extracted with EtOAc $(3 \times 15 \mathrm{~mL})$. The organic layers were combined, dried over $\mathrm{MgSO}_{4}$, and solvents were removed under vacuum. The crude product was purified twice by flashcolumn chromatography (silica gel, cyclohexane/EtOAc as gradient from 100:0 to $90: 10,80: 20,70: 30$ and $60: 40 \mathrm{v} / \mathrm{v}$ ) to furnish the title compound ( $72 \mathrm{mg}, 0.19 \mathrm{mmol}, 76 \%$ yield) as a colorless oil. Two stereoisomers were observed by NMR in a ratio of 1:1. IR (neat): 2939, 1766, 1693, 1378, 1354, 1219, $1188,911,835,768,729,698 .{ }^{1} \mathrm{H}$ NMR $\left(300 \mathrm{MHz} \mathrm{CDCl}_{3}\right): \delta$ 8.67 (bs, $1 \mathrm{H}), 7.40-7.33(\mathrm{~m}, 2 \mathrm{H}), 7.33-7.23(\mathrm{~m}, 3 \mathrm{H}), 6.17-$ $6.09(\mathrm{~m}, 1 \mathrm{H}), 6.02-5.94(\mathrm{~m}, 1 \mathrm{H}), 5.26(\mathrm{q}, J=7.3 \mathrm{~Hz}, 1 \mathrm{H}), 3.83-$ $3.69(\mathrm{~m}, 2 \mathrm{H}), 3.17-3.05(\mathrm{~m}, 2 \mathrm{H}), 2.24$ (overlaped triplet, $J=$ $7.3 \mathrm{~Hz}, 2 \mathrm{H}$ ), 1.97 (overlaped triplet, $J=7.3 \mathrm{~Hz}, 2 \mathrm{H}$ ), 1.69 (d, $J=$
$7.3 \mathrm{~Hz}, 3 \mathrm{H}$, overlaped with signal at $1.68 \mathrm{ppm}), 1.68(\mathrm{dt}, J=7.3$, $7.3 \mathrm{~Hz}, 2 \mathrm{H}$, overlaped with signal at $1.69 \mathrm{ppm}$ ), 1.55 (overlaped singlet, $3 \mathrm{H}$ ). ${ }^{13} \mathrm{C}$ NMR $\left(75 \mathrm{MHz}, \mathrm{CDCl}_{3}\right): \delta 179.1,177.0,176.9$, $148.7,139.4,134.6,134.6,134.5,128.1,127.6,113.6,50.0$, $44.76,44.72,44.70,44.66,44.52,44.46,44.41,44.35,32.94$, 32.60, 22.6, 16.9, 16.4. HRMS (ESI-) Calculated for $\mathrm{C}_{23} \mathrm{H}_{24} \mathrm{NO}_{4}$ $[\mathrm{M}-\mathrm{H}]^{-}: 378.1705$; found : 378.1703. HPLC System $B(\lambda=254$ $\mathrm{nm}) t_{\mathrm{R}}=4.36 \mathrm{~min}$.

Cycloadduct cyclohexadiene-chiral maleimide (23). To a solution of cyclohexa-2,4-dien-1-ylmethyl (6hydroxyhexyl)carbamate 4 (38 $\mathrm{mg}, 0.15 \mathrm{mmol}, 1.0$ equiv.) in a solution of $\mathrm{THF} / \mathrm{H}_{2} \mathrm{O}(1 \mathrm{~mL}, 2: 1 \mathrm{v} / \mathrm{v})$ was added a solution of 19 (30 mg, $0.15 \mathrm{mmol}, 1.0$ equiv.) in $\mathrm{THF} / \mathrm{H}_{2} \mathrm{O}(1 \mathrm{~mL}, 2: 1 \mathrm{v} / \mathrm{v})$. The mixture was stirred at room temperature for 3 days. After completion, the reaction mixture was diluted with water (10 $\mathrm{mL})$ and the aqueous layer extracted with EtOAc $(3 \times 15 \mathrm{~mL})$. The organic layers were combined, dried over $\mathrm{MgSO}_{4}$, and solvents were removed under vacuum. The crude product was purified twice by flash-column chromatography (silica gel, cyclohexane/EtOAc as gradient from 100:0 to 90:10, 80:20, $70: 30$ and $60: 40 \mathrm{v} / \mathrm{v}$ ) to furnish the title compound (48 mg, $0.11 \mathrm{mmol}, 70 \%$ yield) as a white foam. Two stereoisomers were observed by NMR in a ratio of 1:1. IR (neat): 3358, 2931, 2860, 1687, 1528, 1453, 1361, 1234, 1190, 1056, 1024, 698. ${ }^{1} \mathrm{H}$ NMR (300 MHz, $\left.\mathrm{CDCl}_{3}\right): \delta 7.39-7.30(\mathrm{~m}, 5 \mathrm{H}), 7.30-7.27(\mathrm{~m}$, $3 \mathrm{H}), 7.25-7.19(\mathrm{~m}, 2 \mathrm{H}) 6.20-5.88(\mathrm{~m}, 4 \mathrm{H}), 5.30(\mathrm{q}, J=7.3 \mathrm{~Hz}$, $2 \mathrm{H}), 4.64(\mathrm{bs}, 2 \mathrm{H}), 3.79(\mathrm{dd}, J=10.8,5.8 \mathrm{~Hz}, 2 \mathrm{H}), 3.64(\mathrm{t}, J=6.5$ $\mathrm{Hz}, 2 \mathrm{H}), 3.64(\mathrm{t}, J=6.5 \mathrm{~Hz}, 2 \mathrm{H}), 3.59-3.47(\mathrm{~m}, 3 \mathrm{H}), 3.25-3.03$ $(\mathrm{m}, 9 \mathrm{H}), 2.86-2.67(\mathrm{~m}, 4 \mathrm{H}), 2.18-1.96(\mathrm{~m}, 2 \mathrm{H}), 1.94-1.74$ $(\mathrm{m}, 1 \mathrm{H}), 1.68(\mathrm{~d}, J=7.3 \mathrm{~Hz}, 6 \mathrm{H}), 1.61-1.44(\mathrm{~m}, 10 \mathrm{H}), 1.44-$ $1.27(\mathrm{~m}, 10 \mathrm{H}), 1.21(\mathrm{t}, J=7.0 \mathrm{~Hz}, 3 \mathrm{H}), 1.14(\mathrm{~d}, J=6.6 \mathrm{~Hz}, 3 \mathrm{H})$ $0.98-0.70(\mathrm{~m}, 4 \mathrm{H}) .{ }^{13} \mathrm{C}$ NMR $\left(75 \mathrm{MHz}, \mathrm{CDCl}_{3}\right): \delta 178.4,178.4$, $178.21,156.4,139.4,133.0,132.8,130.1,129.9,128.1,127.5$, $127.4,66.9,62.6,49.9,43.8,43.8,43.4,43.3,40.8,35.9,33.5$, $32.5,32.0,29.9,27.8,27.8,26.3,25.3,16.4,16.4$. HRMS (ESI+) Calculated for $\mathrm{C}_{26} \mathrm{H}_{35} \mathrm{~N}_{2} \mathrm{O}_{5}[\mathrm{M}+\mathrm{H}]^{+}$: 455.2546 ; found : 455.2538. HPLC System $A(\lambda=254 \mathrm{~nm}) t_{\mathrm{R}}=4.09 \mathrm{~min}$.

Cycloadduct anthracene-chiral maleimide (24). To a solution of anthracen-9-ylmethanol $5(52 \mathrm{mg}, 0.25 \mathrm{mmol}, 1.0$ equiv.) in a solution of $\mathrm{THF} / \mathrm{H}_{2} \mathrm{O}(1 \mathrm{~mL}, 2: 1 \mathrm{v} / \mathrm{v})$ was added a solution of 19 (50 mg, $0.25 \mathrm{mmol}, 1.0$ equiv.) in $\mathrm{THF} / \mathrm{H}_{2} \mathrm{O}$ (1 $\mathrm{mL}, 2: 1 \mathrm{v} / \mathrm{v})$. The mixture was stirred at room temperature for $120 \mathrm{~h}$. After completion, the reaction mixture was diluted with water $(10 \mathrm{~mL})$ and the aqueous layer extracted with EtOAc $(2 \times$ $15 \mathrm{~mL}$ ). The organic layers were combined, dried over $\mathrm{MgSO}_{4}$, and solvents were removed under vacuum. The crude product was purified by flash-column chromatography (silica gel, cyclohexane/EtOAc as gradient from 100:0 to 50:50, v/v) to provide the title compound ( $56 \mathrm{mg}, 0.14 \mathrm{mmol}, 54 \%$ yield) as a colorless solid. Two stereoisomers were observed by NMR in a ratio of 0.8:1. IR (neat): 3448, 3065, 3031, 2969, 2941, 1688, 1457, 1359, 1221, 1195, 907, 728, 696. ${ }^{1} \mathrm{H}$ NMR $(300 \mathrm{MHz}$, $\left.\mathrm{CDCl}_{3}\right): \delta 7.61(\mathrm{dd}, J=5.2,3.6 \mathrm{~Hz}, 1.7 \mathrm{H}), 7.40-7.30(\mathrm{~m}, 2.7 \mathrm{H})$, $7.29-7.26(\mathrm{~m}, 1.1 \mathrm{H}), 7.26-7.22(\mathrm{~m}, 2.4 \mathrm{H}) 7.21-7.09(\mathrm{~m}$, $13.4 \mathrm{H}), 6.99-6.91(\mathrm{~m}, 2 \mathrm{H}), 6.90-6.82(\mathrm{~m}, 1.6 \mathrm{H}), 5.13(\mathrm{dt}, J=$ 12.8, $6.7 \mathrm{~Hz}, 1.3 \mathrm{H}), 5.07-4.84(\mathrm{~m}, 4.2 \mathrm{H}), 4.76(\mathrm{~d}, J=3.3 \mathrm{~Hz}$, 
$0.8 \mathrm{H}), 4.73(\mathrm{~d}, J=2.9 \mathrm{~Hz}, 0.9 \mathrm{H}), 3.35-3.20(\mathrm{~m}, 3.6 \mathrm{H}), 2.70(\mathrm{t}, J$ $=6.3 \mathrm{~Hz}, 1.1 \mathrm{H}), 2.67(\mathrm{t}, J=6.3 \mathrm{~Hz}, 1 \mathrm{H}), 1.31(\mathrm{~d}, J=7.3 \mathrm{~Hz}, 2.4 \mathrm{H})$, $1.24(\mathrm{~d}, J=6.2 \mathrm{~Hz}, 3 \mathrm{H}) .{ }^{13} \mathrm{C} \mathrm{NMR}\left(75 \mathrm{MHz}, \mathrm{CDCl}_{3}\right): \delta 176.7$, $176.6,176.5,176.4,142.2,142.2$, 142.2, 139.3, 139.3, 139.0, $138.5,138.5,128.2,127.3,127.2,126.9,126.8,126.8,126.7$, $126.5,126.4,125.2,123.9,123.9,123.2,123.2,122.3,60.2$, 60.1, 49.6, 49.5, 49.3, 49.3, 47.4, 47.4, 45.6, 45.5, 45.5, 15.84, 15.7. HRMS (ESI+) Calculated for $\mathrm{C}_{27} \mathrm{H}_{24} \mathrm{NO}_{4}[\mathrm{M}+\mathrm{H}]^{+}: 410.1756$ ; found : 410.1757. HPLC System $A(\lambda=254 \mathrm{~nm}) t_{\mathrm{R}}=4.67 \mathrm{~min}$.

Cycloadduct furan-chiral maleimide (25). To a solution of furan-2-ylmethanol $6(24.5 \mathrm{mg}, 0.25 \mathrm{mmol}, 1.0$ equiv.) in a solution of THF/ $\mathrm{H}_{2} \mathrm{O}(1 \mathrm{~mL}, 2: 1, \mathrm{v} / \mathrm{v})$ was added a solution of 19 (50 mg, $0.25 \mathrm{mmol}, 1.0$ equiv.) in THF/ $\mathrm{H}_{2} \mathrm{O}(1 \mathrm{~mL}, 2: 1, \mathrm{v} / \mathrm{v})$. The mixture was stirred at room temperature for $48 \mathrm{~h}$. After completion, the reaction mixture was diluted with water (10 $\mathrm{mL})$ and the aqueous layer extracted with EtOAc $(2 \times 15 \mathrm{~mL})$. The organic layers were combined and dried over $\mathrm{MgSO}_{4}$, and solvents were removed under vacuum. The crude product was purified by flash-column chromatography (silica gel, cyclohexane/EtOAc as gradient from 100:0 to 70:30 and finally $50: 50, \mathrm{v} / \mathrm{v}$ ) to furnish the title compound $(60 \mathrm{mg}, 0.20 \mathrm{mmol}$, $80 \%$ yield) as a colorless oil. Three stereoisomers were observed by NMR in a ratio of 0.7:1:1. IR (neat): 3449, 2925, 2857, 1691, 1378, 1356, 1219, 1188, 1025, 983, 969, 730, 697. ${ }^{1} \mathrm{H}$ NMR $\left(300 \mathrm{MHz}, \mathrm{CDCl}_{3}\right): \delta 7.41-7.27(\mathrm{~m}, 13.2 \mathrm{H}), 6.60(\mathrm{dd}, J$ $=5.7,1.5 \mathrm{~Hz}, 0.7 \mathrm{H}), 6.55-6.50(\mathrm{~m}, 0.7 \mathrm{H}), 6.28(\mathrm{dd}, J=5.8,1.7$ $\mathrm{Hz}, 1 \mathrm{H}), 6.20(\mathrm{~d}, J=5.8 \mathrm{~Hz}, 1 \mathrm{H}), 6.12(\mathrm{dd}, J=5.8,1.7 \mathrm{~Hz}, 1 \mathrm{H})$, $6.02(\mathrm{~d}, J=5.8 \mathrm{~Hz}, 0.9 \mathrm{H}), 5.39(\mathrm{q}, J=7.3 \mathrm{~Hz}, 0.9 \mathrm{H}), 5.30-5.15$ $(\mathrm{m}, 4.8 \mathrm{H}), 4.29-4.06(\mathrm{~m}, 5.4 \mathrm{H}), 4.03-3.83(\mathrm{~m}, 1.4 \mathrm{H}), 3.58$ (dd, $J=7.8,5.4 \mathrm{~Hz}, 1.9 \mathrm{H}), 3.32(\mathrm{dd}, J=7.8,1.7 \mathrm{~Hz}, 2 \mathrm{H}), 2.95$ $(\mathrm{dd}, J=6.6,1.0 \mathrm{~Hz}, 0.8 \mathrm{H}), 2.92-2.89(\mathrm{~m}, 0.8 \mathrm{H}), 2.76(\mathrm{dt}, J=$ 28.2, $7 \mathrm{~Hz}, 1 \mathrm{H}), 2.12-2.02(\mathrm{~m}, 2 \mathrm{H}), 1.80(\mathrm{~d}, J=7.4 \mathrm{~Hz}, 2 \mathrm{H})$, $1.70(\mathrm{~d}, J=7.6 \mathrm{~Hz}, 5.7 \mathrm{H}) .{ }^{13} \mathrm{C}$ NMR $\left(75 \mathrm{MHz} \mathrm{CDCl}_{3}\right): \delta 175.9$, $175.8,175.7,175.7,175.1,175.0,174.6,170.6,167.7,142.4$, $140.2,139.0,138.9,138.9,138.8,138.4,138.3,136.9,136.8$, $135.3,135.2,134.6,134.5,133.9,132.4,130.8,128.4,128.4$, $128.31,128.1,128.1,127.8,127.6,127.6,127.5,127.1,127.0$, $126.9,110.3,107.6,92.2,92.2,91.5,91.4,81.0,80.7,79.6$ $79.6,68.1,67.9,61.3,61.3,60.7,60.5,57.3,50.3,50.1,50.1$ $49.6,49.6,47.7,47.7,47.5,47.47,45.6,45.5,38.6,30.3,29.6$, $28.8,25.5,23.7,22.9,17.6,16.4,15.9,15.9,14.0,10.9$. HRMS $(\mathrm{ESI}+)$ Calculated for $\mathrm{C}_{17} \mathrm{H}_{18} \mathrm{NO}_{4}[\mathrm{M}+\mathrm{H}]^{+}: 300.1236$; found : 300.1240. HPLC System $A(\lambda=254 \mathrm{~nm}) t_{\mathrm{R}}=3.20 \mathrm{~min}, 3.25 \mathrm{~min}$.

Azaphthalimide (26). To a solution of 6-(5-ethoxy-2methyloxazol-4-yl)hexanoic acid $8(60 \mathrm{mg}, 0.25 \mathrm{mmol}, 1.0$ equiv.) in a solution of THF/ $\mathrm{H}_{2} \mathrm{O}(1 \mathrm{~mL}, 2: 1 \mathrm{v} / \mathrm{v})$ were added a solution of 19 (50 mg, $0.25 \mathrm{mmol}, 1.0$ equiv.) in THF/ $\mathrm{H}_{2} \mathrm{O}((1$ $\mathrm{mL}, 2: 1 \mathrm{v} / \mathrm{v})$ and TFA (19 $\mu \mathrm{L}, 0.25 \mathrm{mmol}, 1.0$ equiv.). The mixture was stirred at room temperature for $24 \mathrm{~h}$. After completion, the reaction mixture was diluted with water (10 $\mathrm{mL})$ and the aqueous layer extracted with EtOAc $(3 \times 15 \mathrm{~mL})$. The organic layers were combined, dried over $\mathrm{MgSO}_{4}$, and solvents were removed under vacuum. The crude product was purified by RP-HPLC (System D) and fractions were collected and lyophilized to furnish the title compound $(61 \mathrm{mg}, 0.12$ $\mathrm{mmol}, 48 \%$ yield) as a yellow powder. One stereoisomer was observed by NMR. IR (neat): 3375, 2941, 2865, 1699, 1393, $1335,1197,1146,1061,759,698 .{ }^{1} \mathrm{H}$ NMR $\left(300 \mathrm{MHz}, \mathrm{CD}_{3} \mathrm{CN}+\right.$ $5 \%$ methanol-d4): $\delta 7.47-7.23(\mathrm{~m}, 5 \mathrm{H}), 5.49(\mathrm{q}, J=7.4 \mathrm{~Hz}$, $1 \mathrm{H}), 2.89(\mathrm{t}, J=7.6 \mathrm{~Hz}, 2 \mathrm{H}), 2.66(\mathrm{~s}, 3 \mathrm{H}), 2.27(\mathrm{t}, J=7.4 \mathrm{~Hz}, 2 \mathrm{H})$, $1.85(\mathrm{~d}, J=7.3 \mathrm{~Hz}, 3 \mathrm{H}), 1.72(\mathrm{dd}, J=15.1,7.7 \mathrm{~Hz}, 2 \mathrm{H}), 1.66-$ $1.54(\mathrm{~m}, 2 \mathrm{H}), 1.47-1.34(\mathrm{~m}, 2 \mathrm{H}) .{ }^{13} \mathrm{C}$ NMR $\left(75 \mathrm{MHz}, \mathrm{CD}_{3} \mathrm{CN}+\right.$ $5 \%$ methanol-d4): $\delta 176.2,168.8,160.4,146.8,146.5,141.7$, 129.6, 128.7, 128.1, 122.8, 122.1, 118.6, 50.5, 34.5, 32.7, 29.7, 28.7, 25.6, 19.5, 17.9. HRMS (ESI-) Calculated for $\mathrm{C}_{22} \mathrm{H}_{23} \mathrm{~N}_{2} \mathrm{O}_{5}$ $[\mathrm{M}-\mathrm{H}]^{-}: 395.1607$; found : 395.1617. HPLC System $A(\lambda=254$ $\mathrm{nm}) t_{\mathrm{R}}=4.22 \mathrm{~min}$.

Azaphtalimide model (AM).To a solution of 4-benzyl-5ethoxy-2-methyloxazole 9 (54 mg, $0.25 \mathrm{mmol}, 1.0$ equiv.) in a solution of $\mathrm{THF} / \mathrm{H}_{2} \mathrm{O}(1 \mathrm{~mL}, 2: 1 \mathrm{v} / \mathrm{v})$ were successively added a solution of 19 ( $50 \mathrm{mg}, 0.25 \mathrm{mmol}, 1.0$ equiv) in $\mathrm{THF} / \mathrm{H}_{2} \mathrm{O}(1 \mathrm{~mL}$, $2: 1 \mathrm{v} / \mathrm{v})$ and TFA $(20 \mu \mathrm{L}, 0.25 \mathrm{mmol}, 1.0$ equiv.). The mixture was stirred at room temperature for $24 \mathrm{~h}$. After completion, the reaction mixture was diluted with water $(10 \mathrm{~mL})$ and the aqueous layer extracted with EtOAc $(2 \times 15 \mathrm{~mL})$. The organic layers were combined, dried over $\mathrm{MgSO}_{4}$, and solvents were removed under vacuum. The crude product was purified by flash-column chromatography (silica gel, cyclohexane/EtOAc as gradient from 100:0 to 95:5) to yield the title compound (70 $\mathrm{mg}, 0.19 \mathrm{mmol}, 75 \%$ yield) as a yellow oil. One stereoisomer was observed by NMR. IR (neat): 3430, 3088, 3064, 3029, 2979, 2933, 1764, 1695, 1602, 1395, 1362, 1328, 1146, 953, $906,726,695 .{ }^{1} \mathrm{H}$ NMR $\left(300 \mathrm{MHz}, \mathrm{CDCl}_{3}\right): \delta 7.50-7.41(\mathrm{~m}, 3 \mathrm{H})$, $7.38-7.14(\mathrm{~m}, 7 \mathrm{H}), 5.48(\mathrm{q}, J=7.3 \mathrm{~Hz}, 1 \mathrm{H}), 4.24(\mathrm{~s}, 2 \mathrm{H}), 2.74$ (s, 3H), 1.89 (d, $J=7.3 \mathrm{~Hz}, 3 \mathrm{H}) \cdot{ }^{13} \mathrm{C}$ NMR $\left(75 \mathrm{MHz}, \mathrm{CDCl}_{3}\right): \delta$ 169.0, 167.6, 156.9, 147.5, 145.3, 139.6, 137.6, 129.1, 128.5, $128.4,127.9,127.3,126.5,120.4,119.7,49.7,38.8,20.1,17.3$. HRMS (ESI+) Calculated for $\mathrm{C}_{20} \mathrm{H}_{21} \mathrm{~N}_{2} \mathrm{O}_{3}[\mathrm{M}+\mathrm{H}]^{+}: 373.1552$; found : 373.1550 . HPLC System A $(\lambda=254 \mathrm{~nm}) t_{\mathrm{R}}=5.09 \mathrm{~min}$.

\section{Preparation of Michael adducts}

Thio Michael adduct (27). To a solution of $19(25 \mathrm{mg}, 0.12$ mmol, 1.0 equiv) in a solution of MeCN/PBS pH $7.4(1 \mathrm{~mL}, 1: 1$, $\mathrm{v} / \mathrm{v}$ ) was added $\mathrm{N}$-acetylcysteine $(23 \mathrm{mg}, 0.14 \mathrm{mmol}, 1.2$ equiv). The mixture was stirred at room temperature for $2 \mathrm{~h}$. After completion, the reaction mixture was diluted with water $(10 \mathrm{~mL})$ and the aqueous layer extracted with EtOAc $(2 \times 15$ $\mathrm{mL}$ ). The organic layers were combined, dried over $\mathrm{MgSO}_{4}$, and solvents were removed under vacuum. The crude product was purified twice by RP-HPLC (System D) and fractions were collected and lyophilized to furnish the title compound $(20 \mathrm{mg}$, $0.055 \mathrm{mmol}, 46 \%$ yield) as a lyophilized white powder. Two stereoisomers were observed by NMR in a ratio of $1: 1$. IR (neat) 3342, 3276, 2985, 2941, 2106, 1695, 1538, 1362, 1219, $1183,765,698 .{ }^{1} \mathrm{H}$ NMR $(300 \mathrm{MHz}$, methanol-d4): $\delta 7.42-7.20$ $(\mathrm{m}, 10 \mathrm{H}), 5.37(\mathrm{q}, J=7.3 \mathrm{~Hz}, 2 \mathrm{H}), 4.71(\mathrm{dd}, J=9.1,4.4 \mathrm{~Hz}, 1 \mathrm{H})$, $4.64(\mathrm{t}, J=6.3 \mathrm{~Hz}, 1 \mathrm{H}), 3.94(\mathrm{t}, J=3.6 \mathrm{~Hz}, 1 \mathrm{H}), 3.91(\mathrm{t}, J=3.6$ $\mathrm{Hz}, 1 \mathrm{H}), 3.51$ (dd, $J=13.9,4.4 \mathrm{~Hz}, 1 \mathrm{H}), 3.24-3.17(\mathrm{~m}, 2 \mathrm{H}), 3.17$ $-3.10(\mathrm{~m}, 2 \mathrm{H}), 2.91(\mathrm{dd}, J=13.9,9.2 \mathrm{~Hz}, 1 \mathrm{H}), 2.50(\mathrm{dd}, J=18.6$, $3.9 \mathrm{~Hz}, 1 \mathrm{H}), 2.38(\mathrm{dd}, J=18.6,3.6 \mathrm{~Hz}, 1 \mathrm{H}), 2.00(\mathrm{~s}, 3 \mathrm{H}), 1.99(\mathrm{~s}$, $3 \mathrm{H}), 1.79(\mathrm{~d}, J=0.8 \mathrm{~Hz}, 3 \mathrm{H}), 1.77(\mathrm{~d}, J=0.8 \mathrm{~Hz}, 3 \mathrm{H}) .{ }^{13} \mathrm{C} N \mathrm{NMR}$ (75 MHz, methanol-d4): $\delta$ 178.5, 178.3, 176.6, 176.5, 173.4, $173.4,173.3,141.0,141.0,129.4,129.4,128.6,128.2,128.1$, 53.7, 52.9, 51.6, 51.5, 41.3, 39.9, 37.1, 36.6, 34.3, 34.1, 22.4, 
16.9, 16.8. HRMS (ESI+) Calculated for $\mathrm{C}_{17} \mathrm{H}_{21} \mathrm{~N}_{2} \mathrm{O}_{5} \mathrm{~S}[\mathrm{M}+\mathrm{H}]^{+}$: 365.1171 ; found : 365.1165 . HPLC System $\mathrm{A}(\lambda=254 \mathrm{~nm}) t_{\mathrm{R}}=$ $3.23 \mathrm{~min}$.

\section{Conflicts of interest}

There are no conflicts to declare.

\section{Acknowledgements}

The authors thank Agence National pour la Recherche (ANR) for Ph.D fellowship to A.L. and the Region Haute-Normandie (FEDER CHIMBIO HN 0001401) for financial support to K.R. This work was also supported by the Centre National de la Recherche Scientifique (CNRS), Rouen University and INSA de Rouen. The authors also acknowledge Albert Marcual (CNRS) and Dr Corinne Bourhis-Loutelier (Rouen University) for HMRS analyses and Dr Pierre Bohn (Centre Henry Bequerel / CHU de Rouen) and $\mathrm{Dr}$ Morgane Detraz (Rouen University) for providing HBP. Dr Vincent Aucagne (Centre de Biophysique Moléculaire d'Orléans) is warmly acknowledged for helpful discussions.

\section{Notes and references}

1 L. S.Witus, and M. B. Francis. Acc. Chem. Res. 2011, 44, 774.

2 P. Akkapeddi, S. A. Azizi, A. M. Freedy, P. Cal, P. M. P. Gois, and G. J. L. Bernardes. Chem. Sci., 2016, 7, 2954.

3 G. T. Hermanson. Bioconjugate Technique, 3rd ed. Elsevier Waltham, MA (2013).

4 K. Renault, J. W. Fredy, P.-Y. Renard, and C. Sabot. Bioconjugate Chem., 2018, 29, 2497.

5 N. Joubert, C. Denevault-Sabourin, F. Bryden, and M. C. Viaud-Massuard. Eur. J. Med. Chem., 2017, 142, 393.

6 V. Pozsgay, N. E. Vieira, and A. A. Yergey. Org. Lett., 2002, 4 3191.

7 A. D. de Araujo, J. M. Palomo, J. Cramer, O. Seitz, K Alexandrov, and H. Waldmann. Chem. Eur. J., 2006, 12, 6095.

8 L.-A. Jouanno, A. Chevalier, N. Sekkat, N. Perzo, H. Castel, A. Romieu, N. Lange, C. Sabot, and P.-Y. Renard. J. Org. Chem., 2014, 79, 10353.

9 A. H. St Amant, D. Lemen, S. Florinas, S. Mao, C. Fazenbaker, H. Zhong, H. Wu, C. Gao, R. J. Christie, and J. Read de Alaniz. Bioconjugate Chem., 2018, 29, 2406.

10 A. H. St Amant, F. Huang, J. Lin, D. Lemen, C. Chakiath, S. Mao, C. Fazenbaker, H. Zhong, J. Harper, W. Xu, et al. Bioconjugate Chem., 2019, 30, 2340-2348.

11 B. Seelig, and A. Jäschke. Tetrahedron Lett. 1997, 38, 7729.

12 K. W. Hill, J. Taunton-Rigby, J. D. Carter, E. Kropp, K. Vagle, W. Pieken, D. P. McGee, G. M. Husar, M. Leuck, D. J. Anziano, and D. P. Sebesta. J. Org. Chem., 2001, 66, 5352.

13 V. Marchan, S. Ortega, D. Pulido, E. Pedroso, and A. Grandas. Nucleic Acids Res., 2006, 34, e24.

14 V. Steven, and D. Graham. Org. Biomol. Chem. 2008, 6, 3781.

15 X. L. Sun, C. L. Stabler, C. S. Cazalis, and E. L. Chaikof. Bioconjugate Chem., 2006, 17, 52.

16 A. Petrelli, E. Samain, S. Pradeau, S. Halila, and S. Fort. ChemBioChem 2017, 18, 206.

17 A. H. St Amant, F. Huang, J. Lin, K. Rickert, V. Oganesyan, D. Lemen, S. Mao, J. Harper, M. Marelli, H. Wu, et al. Angew. Chem., Int. Ed., 2019, 58, 8489.
18 L. I. Willems, M. Verdoes, B. I. Florea, G. van der Marel, and H. S. Overkleeft. ChemBioChem 2010, 11, 1769.

19 S. Y. Tang, J. Shi, and Q. X. Guo. Org. Biomol. Chem., 2012, 10, 2673.

20 J. S. Fell, B. N. Martin, and K. N. Houk. J. Org. Chem., 2017, 82, 1912.

21 S. Yu, H. M. de Bruijn, D. Svatunek, T. A. Hamlin, and F. M. Bickelhaupt. ChemistryOpen 2018, 7, 995.

22 V. Borsenberger, and S. Howorka. Nucleic Acids Res., 2009, 37, 1477.

23 A. H. El-Sagheer, V. V. Cheong, and T. Brown. Org. Biomol. Chem., 2011, 9, 232.

24 X. L. Sun, L. Yang, and E. L. Chaikof. Tetrahedron Lett., 2008, 49, 2510.

25 N. Coskun, I. Erden. Tetrahedron 2011, 67, 8607.

26 Y. Liu, R. K. Goswami, C. Liu, and S. C. Sinha. Mol. Pharm. 2015, 12, 2544.

27 V. A. Mironov, E. V. Sobolev, and A. N. Elizarova. Tetrahedron 1963, 19, 1939.

28 C. Sabot, E. Oueis, X. Brune, and P.-Y. Renard. Chem. Commun., 2012, 48, 768.

29 L.-A. Jouanno, C. Sabot, and P.-Y. Renard. J. Org. Chem., 2012, 77, 8549.

30 L.-A. Jouanno, V. Tognetti, L. Joubert, C. Sabot, and P.-Y. Renard. Org. Lett., 2013, 15, 2530.

31 L.-A. Jouanno, V. Di Mascio, V. Tognetti, L. Joubert, C. Sabot, and P.-Y. Renard. J. Org. Chem., 2014, 79, 1303.

32 A. Lizzul-Jurse, L. Bailly, M. Hubert-Roux, C. Afonso, P.-Y. Renard, and C. Sabot. Org. Biomol. Chem., 2016, 14, 7777.

33 K. Renault, L.-A. Jouanno, A. Lizzul-Jurse, P.-Y. Renard, and C. Sabot, C. Chem. Eur. J., 2016, 22, 18522.

34 J. E. T. Corrie. J. Chem. Soc., Perkin Trans. 1, 1994, 2975.

35 D. Kand, A. M. Kalle, and P. Talukdar. Org. Biomol. Chem., 2013, 11, 1691.

36 G. Viault, S. Dautrey, N. Maindron, J. Hardouin, P.-Y. Renard, and A. Romieu. Org. Biomol. Chem., 2013, 11, 2693.

37 L. Cheng, X. Kang, D. Wang, Y. Gao, L. Yi, and Z. Xi. Org. Biomol. Chem., 2019, 17, 5675.

38 T. Yokoi, T. Ueda, H. Tanimoto, T. Morimoto, and K. Kakiuchi. Chem. Commun., 2019, 55, 1891.

39 D. M. Beal, and L. H. Jones. Angew. Chem. Int. Ed., 2012, 51, 6320.

40 D. M. Patterson, and J. A. Prescher. Curr. Opin. Chem. Biol., 2015, 28, 141.

41 C. Simon, C. Lion, C. Spriet, F. Baldacci-Cresp, S. Hawkins, and C. Biot, C. Angew. Chem. Int. Ed., 2018, 57, 16665.

42 J. E. T. Corrie, V. R. N. Munasinghe, and W. Rettig. J. Heterocycl. Chem., 2000, 37, 1447.

43 K. Hoogewijs, D. Buyst, J. M. Winne, J. C. Martins, and A. Madder, A. Chem. Commun., 2013, 49, 2927.

44 J. E. Montgomery, J. A. Donnelly, S. W. Fanning, T. E. Speltz, X. Shangguan, J. S. Coukos, G. L. Greene, and R. E. Moellering. J. Am. Chem. Soc., 2019, 141, 16374.

45 S. D. Fontaine, R. Reid, L. Robinson, G. W. Ashley, and D. V. Santi. Bioconjugate Chem., 2015, 26, 145.

46 D. Kalia, S. P. Pawar, and J. S. Thopate. Angew. Chem., Int Ed., 2017, 56, 1885.

47 L. N. Tumey, M. Charati, T. He, E. Sousa, D. Ma, X. Han, T. Clark, J. Casavant, F. Loganzo, F. Barletta, J. Lucas, and E. I. Graziani. Bioconjugate Chem., 2014, 25, 1871.

48 R. P. Lyon, J. R. SetterT. D. Bovee, S. O. Doronina, J. H. Hunter, M. E. Anderson, C. L. Balasubramanian, S. M. Duniho, C. I. Leiske, F. Li, and P. D. Senter. Nat. Biotechnol., 2014, 32, 1059

49 K. Renault, P.-Y. Renard, and C. Sabot. Eur. J. Org. Chem. 2018, 46, 6494

$50 \mathrm{~J}$. Carneiro de Oliveira, M.-P. Laborie, and V. Roucoules. Molecules 2020, 25, 243. 
51 E. Gil de Montes, A. Istrate, C. D. Navo, E. Jiménez-Moreno, E. A. Hoyt, F. Corzana, I. Robina, G. Jiménez-Osés, A. J. Moreno-Vargas, and G. J. L. Bernardes. Angew. Chem., Int. Ed., 2020, https://doi.org/10.1002/ange.201914529.

52 A. H. St. Amant, E. H. Discekici, S. J. Bailey, M. S. Zayas, J.-A. Song, S. L. Shankel, S. N. Nguyen, M. W. Bates, A. Anastasaki, C. J. Hawker et al. J. Am. Chem. Soc. 2019, 141, 34, 13619.

53 K. Lang, and J. W. Chin. ACS Chem. Biol., 2014, 9, 16.

54 S. N. Lam, P. Acharya, R. Wyatt, P.D. Kwong, and C. A. Bewley. Bioorg. Med. Chem., 2008, 16, 10113.

55 C. E. Puerto Galvis, and V. V. Kouznetsov. Org. Biomol. Chem., 2013, 11, 407. 